\begin{tabular}{|c|c|c|c|}
\hline & $\begin{array}{l}\text { FATIH } \\
\text { SULTAN } \\
\text { MEHMET } \\
\text { vakIF ÜNivERSiTESi }\end{array}$ & $\begin{array}{l}\text { FSM İlmî Araştırmalar Insan ve Toplum Bilimleri Dergisi } \\
\text { ESM Scholarly Studies Journal of Humanities and Social Sciences } \\
\text { Sayı/Number } 16 \text { Yıl/Year } 2020 \text { Güz/Autumn } \\
\text { (c)2020 Fatih Sultan Mehmet Vakıf Üniversitesi }\end{array}$ & 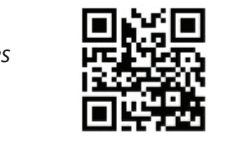 \\
\hline DOI: & & http://dergipark.org.tr/fsmia & http://dergi.fsm.edu.tr \\
\hline Araştırm & lesi / Research Article & Geliş Tarihi / Received: 22.09.2020 Kabul Tarihi / Accepted: 04.12.2020 & FSMIAD, 2020; (16): 133-171 \\
\hline
\end{tabular}

\title{
İran'da Osmanlı Kaza İdaresinin Kurulması ve Kadı Tevcîhatı (1723-1735)
}

Levent Kuru*

\section{$\ddot{O} z$}

18. yüzyılın başından itibaren Safevi hanedanından memnun olmayan grupların başlattıkları isyanlar İran coğrafyasını istikrarsızlığa sürükledi. Bu durumdan yararlanan Osmanlı Hükümeti Haziran 1723'te İran seferini başlatarak üç koldan Safevi topraklarına girdi. Yapılan fetihlerle birlikte Haziran 1735'e kadar İran sahasında kaldılar.

Osmanlı yönetimi İran'da fethettiği yerleri zaman kaybetmeden kendi idari sistemine dâhil etmek için çalışmalar yapmıştır. Bu makalede; XVIII. yüzyılın ilk yarısında İran'da Osmanlı kaza idaresinin kurulma çalışmaları, kazaların statüleri, sistem tesis edilirken ortaya çıkan aksaklıklar, bunlara karşı alınan tedbirler ve kurulan kazalara yapılan tevcih işlemleri ele alınacaktır.

Anahtar Kelimeler: Osmanlı, Safevi, İran, Kaza, Anadolu Kazaskerliği.

* Dr. Öğr. Üyesi, Milli Savunma Üniversitesi Beşeri ve Sosyal Bilimler Bölümü, İstanbul/Türkiye, leventkuru3@gmail.com, orcid.org/0000-0001-5010-6637 


\title{
Establishment of District Ottoman Administration in Iran and Kadi Assignments (1723-1735)
}

\begin{abstract}
From the beginning of the 18th century, riots initiated by groups that were dissatisfied with the Safavid dynasty caused the Iran's geography to become unstable. The Ottoman Government, who benefited from this situation, started the Iran expedition in June 1723 and entered Safavid territory from three sides. With the conquests, the Ottomans remained in the Iranian area until June 1735.

The Ottoman administration made an endeavour to incorporate the places conquered in Iran into its administrative system without delay. In this article, the establishment of the Ottoman district administration in Iran in the first half of the XVIII. century, the status of districts, problems that occurred during the establishment of the system as well as the measures taken in this regard and the procedures for assignments to the districts established in Iran will be discussed.
\end{abstract}

Keywords: Ottoman, Safavid, Iran, District, Anatolian kadi'asker. 


\section{Giriş}

Osmanlı Devleti doğu komşusu Safevilerle IV. Murad devrinde imzalanan Kasr-1 Şirin Anlaşması'ndan (1639) sonra XVIII. yüzyılın ilk yarısına kadar ciddi bir siyasi ve askeri gerginlik yaşamamıştır. Bu süreçte iki devlet zaman zaman karşılıklı hediyeleşmelerle dostluk ilişkilerini de geliştirmişlerdir' ${ }^{1}$ 1694'te Safevi tahtına oturan Şah Hüseyin'in merkez bürokrasisi, saray ve ulema tesirinde kalmış ve otoritesini kuramamıştır. Bu durum merkezin taşradaki hâkimiyetini zayıflatmıştır. Afgan kabilelerin 1709'da Mir Üveys öncülüğünde ayaklanması ve çıkan karışıklıklar Safevilerin sonunu getiren olaylar zincirini başlatmıştır. Mir Üveys'n oğlu Mir Mahmud önderliğindeki Afgan ordusunun 1722'de İsfahan'1 kuşatmasıyla başlayan 8 aylık süreç sonunda da Şah Hüseyin, 1722 Ekim'inde tacını Mir Mahmud'a teslim etmek zorunda kalmıştır².

Safevilerin zor duruma düşmesi ilk olarak Rusları harekete geçirdi. Çar I. Petro 1722'de Isfahan kuşatma altındayken Hazar Denizi'nin batı kıyılarındaki Safevi topraklarına saldırdı. İran coğrafyasındaki gelişmeleri yakından takip eden Osmanlı Hükümeti sınırdaki valilerin 1srarlarına ve Dağıstanlıların yardım taleplerine rağmen önceleri Safevi meselesine askeri müdahale taraftarı olmadı. Ancak Rusların Hazar Denizi’ne inmesi bu durumu değiştirdi. Kafkaslardaki Rus faaliyetlerini dizginlemek ve Osmanl1-Safevi sınır güvenliğini kontrol altında tutmak isteyen Bâbıâlî, Ekim 1722'de Rusya'ya elçi göndererek bir taraftan diplomatik girişimde bulunurken diğer taraftan askerî müdahale için de hazırlıklara başladi.

1723 yılının bahar aylarında harekete geçen Osmanlı kuvvetleri üç koldan Safevi topraklarına girdi. Böylece Serasker Erzurum Valisi İbrahim Paşa komutasındaki ordu Haziran 1723'te Tiflis önlerine gelirken, Bağdat Valisi Hasan Paşa Kirmanşahan üzerine hareket etti. Batı Azerbaycan'ın en önemli şehri olan Tebriz’in fetih için de Van Valisi Köprülü Abdullah Paşa tayin edildi ${ }^{3}$. Kafkaslarda karşı karşıya gelen Osmanlı Devleti ve Rusya arasında 24 Haziran 1724'te Fransa'nın arabuluculuğu ile bir anlaşma imzalandı ve iki devletin Safevi toprakların-

1 İsmail Hakkı Uzunçarşıl1, Osmanlı Tarihi, VI, Ankara, 1988, s. 131; Rukiye Işı1k, “Osmanlı-İran Seferlerinin Lojistik Hazırlıkları (1630-1750)", (Yayımlanmamış Yüksek Lisans Tezi), Cumhuriyet Üniversitesi Sosyal Bilimler Enstitüsü, Sivas, 2011, s. 8-9.

2 İbrahim Yetiş, “Osmanlı İran Savaşları (1722-1746)”, (Yayımlanmamış Yüksek Lisans Tezi), Muğla S1tkı Koçman Üniversitesi Sosyal Bilimler Enstitüsü, Muğla, 2014, s. 43-45; Raif İvecan, “Osmanlı Hâkimiyetinde Revan (1724-1746)”, (Yayımlanmamış Doktora Tezi), Marmara Üniversitesi Türkiyat Araştırmaları Enstitüsü, İstanbul, 2007, s. 20.

3 Ali Sinan Bilgili, "Osmanlı ve Safevi Hâkimiyetlerinde Tiflis (XVIII. Yüzyıl)”, Türk Kültürü Incelemeleri Dergisi, 21, İstanbul, 2009, s. 23-62. 
daki nüfuz sahaları belirlendi ${ }^{4}$. Bu tarihten sonra Osmanlılar Afgan hâkimiyetindeki yerlerle kendi sınırları arasında kalan sahipsiz toprakları almak için harekete geçtiler. Gence, Revan, Nahcıvan, Urumiye, Tebriz, Erdebil, Kirmanşahan ve Hemedan gibi şehirler ciddi bir direnişle karşılaşmadan kısa sürede fethedildi. Bir taraftan savaşa devam ederken diğer taraftan Afganlılarla barış görüşmeleri çerçevesinde diplomatik ilişkilerini sürdüren Osmanlı Hükümeti Ekim 1727'de Hemedan barışını imzaladı. Bu barış ile Osmanlı Devleti, Safevi topraklarındaki son fetihlerini Afganlara kabul ettirdi ${ }^{5}$.

Safevi tahtını Mir Mahmud'un halefi Eşref Han'dan geri almak için mücadele eden Şehzade Tahmasb'ın, Afşarlı Nadir Han'ın yardımıyla üç savaş sonunda İsfahan'ın ele geçirmesi ve 1729 'da Safevi tahtına çıkması bölgede dengeleri değiştirdi. II. Tahmasb, Temmuz-Ağustos 1730'a kadar bütün Irak-1 Acem topraklarında Osmanlı' dan hakimiyetine son verdi. Tebriz'i de ele geçiren Nadir Han kısa süre içinde tüm Safevi topraklarını geri almayı hedeflemiştir. Ancak bu dönemde Herat Abdalîlerinin isyan etmesi Nadir Han'1n Tebriz'den sonra Revan ve Gence üzerine yürümesini engelledi.

İran coğrafyasında alınan yenilgiler ve yaşanan toprak kayıpları Osmanlı merkezi idaresini sarstı. Patrona Halil liderliğindeki âsiler 1730'da III. Ahmed'i tahttan indirip yerine I. Mahmud'u geçirdiler. Yeni padişah her ne kadar savaşa devam etmek istemese de iç siyasetin etkisiyle muhaliflerinin eline koz vermemek için bütün gücüyle saldırdı. Bu arada Safevi siyasetinde Nadir Han'ın gölgesinde kalan ve tahtını kaybetme endişesine düşen II. Tahmasb, bu durumu ortadan kaldırmak için Osmanlı'nın elinde olan Revan'a saldırdıysa da başarı11 olamadı. Osmanlı kuvvetleri, 1731'de karşı taarruzla Tebriz, Kirmanşahan ve Hemedan'1 aldılar. Daha fazla toprak kaybetmek istemeyen II. Tahmasb mevcut statükoyu kabul ederek Osmanlı Devleti’yle anlaşma imzaladı. Ancak bu durumu

4 Osman Köse, “XVIII. Yüzyılda Osmanl1-Rus Münasebetleri”, Osmanl, I, Ankara, 1999, s. 536-549; Mustafazade Tevfik Teyyüboğlu, "XVIII. Yüzyılın İlk Yarısında Kafkaslarda Osmanl1-Rus İlişkileri”, Osmanlı, I, Ankara, 1999, s. 561-569; Elvin Valiyev, "XVIII. Yüzy1lın İlk Yarısında Güney Kafkasya: Osmanlı, Safevi ve Rusya Kıskacında”, (Yayımlanmamış Yüksek Lisans Tezi), Selçuk Üniversitesi Sosyal Bilimler Enstitüsü, Konya, 2014, s. 67-68; Elvin Valiyev-Doğan Yörük, “Güney Kafkasya'da Osmanlı Hâkimiyeti (1723-1735)”, Selçuk Üniversitesi Türkiyat Araştırmaları Enstitüsü Dergisi (SUTAD), S. 40, 2016, s. 15-28; Selçuk Ilgaz, "Osmanlı Hâkimiyetinde Revan (Çukur Sa'ad) (XVI.-XVIII. Yüzyıllar Arasında Sosyo-Ekonomik Tarih)", (Yayımlanmamış Doktora Tezi), Atatürk Üniversitesi Sosyal Bilimler Enstitüsü, Erzurum, 2010, s. 14.

5 Alper Yıldırım, “I. Mahmud Devri Osmanlı İran İlişkileri”, (Yayımlanmamış Yüksek Lisans Tezi), Osmangazi Üniversitesi Sosyal Bilimler Enstitüsü, Eskişehir, 2017, s. 35. 
kabul etmeyen Nadir Han 1732'de II. Tahmasb'1 tahttan indirdi ve yerine Tahmasb'ın henüz bebek olan oğlu III. Abbas'1 geçirdi. Saltanat vekili makamına da kendisi oturarak devletin tüm kontrolünü eline ald1 ${ }^{6}$.

Nadir Han gibi kararlı bir komutanın Safevi idaresini ele geçirmesi Osman11 Devleti'nin bölgedeki hâkimiyeti için sonun başlangıcı olmuştur. Kısa sürede Hemedan ve Kirmanşahan'1 Osmanlı'dan geri alan Nadir Han 1734'te Dağıstan seferine çıktı. Ardından Gence'yi kuşatarak Köprülüzâde Abdullah Paşa'yı Haziran 1735'te mağlup etti. Bu yenilgiden sonra Revan, Gence ve Tiflis Osmanlı kuvvetlerince tahliye edildi. Nadir, Gence Anlaşması'yla (1735) Rusların elindeki Safevi topraklarını da geri aldı. Nadir Han'ın askeri alanda kazandığı bu başarılar onu iç siyasette istediğini yapabilecek konuma getirdi ve 1736'da Mugan'da Safevi Devleti'ne son vererek İran tahtına çıktı.

Osmanlıların Haziran 1723 tarihinde başlayan İran coğrafyasında hâkimiyet kurma girişimleri Haziran 1735'e gelindiğinde hüsranla sonuçlandı. Bâbıâlî, Kasr-1 Şirin sınırları çerçevesinde yeni bir anlaşma imzalamaya hazır olmasına rağmen Nadir Han'ın Caferilik politikası sulhun hayata geçirilmesini engellemiştir. Bu sebeple iki devlet arasındaki mücadele 1746'ya kadar devam etmiştir. 4 Eylül 1746'da imzalanan Kerden Antlaşması'yla sulh sağlanmış ve 1639 Kasr-1 Şirin Anlaşması'nda çizilen sınırlara geri dönülmüştür?.

\section{Kaynaklar ve Kapsam}

Osmanlı Devleti'nin İran coğrafyasındaki varlığı sadece askeri alanla sınırlı kalmadı. Bâbıâlî, fethettiği yerlerde teamüllere uygun olarak iki yapılı bir idari mekanizma meydana getirdi. Bölge bir taraftan askeri-idari manada eyalet/ liva-sancak/nahiyelere ayrılarak başlarına beylerbeyi, sancakbeyi atamaları yapılırken diğer taraftan hukuki-idari anlamda kaza teşkilatı oluşturuldu. Kazaların başına da "kadı" unvanlı ilmiye kökenli yöneticiler atandı.

Osmanlı Devleti'nde kazalar öncelikle mevleviyet ve kasaba kadılıkları olmak üzere iki ana gruba ayrılmış ve her iki gruptaki kazalar kendi içlerinde derecelendirilmiştir. XVI. yüzyılın ikinci yarısına kadar tüm kazalarla ilgili işlemler Anadolu ve Rumeli kazaskerlerinin yetkisindedir. Bu dönemden sonra üst düzey kadılıklar olan mevleviyetler şeyhülislamın yetkisine geçmiştir. Anadolu ve Ru-

6 İlker Külbilge, “18. Yüzyılın İlk Yarısında Osmanlı İran Siyasi İlişkileri (1703- 1747)”, (Yayımlanmamış Doktora Tezi), Ege Üniversitesi Sosyal Bilimler Enstitüsü, İzmir, 2010, s. 210 211.

7 Uğur Kurtaran, “Sultan Birinci Mahmud ve Dönemi (1730-1754)”, (Yayımlanmamış Doktora Tezi), Selçuk Üniversitesi Sosyal Bilimler Enstitüsü, Konya, 2012, s. 207-210. 
meli kazaskerleri ise mevleviyet derecesinin altında olan kazalarda görev alacak kadıların ve 40 akçeye kadar olan medreselerde görev alacak müderrislerin özlük işlemleriyle ilgilenmişlerdir. Mevleviyet kazalarına yapılan kadı atamaları ruus defterlerine kaydedilirken, kazaskerlerin yetkisindeki kasaba kadılıklarına yapılan atamalar "ruznamçe" adı verilen defterlere kaydedilmiştir8.

İran coğrafyasında ele geçirilen yerlerde ihdas edilen kazalardan Revan, Tebriz ve Hemedan mevleviyet statüsüyle yüksek dereceli kadılık olarak teşkilatlandırıldı. Tiflis ve Gence ise fethedildiklerinde önce mevleviyet statüsüne sokuldu ancak sonra kasaba kadılığına tenzil edildiler. İran'daki mevleviyet derecesinin altındaki kasaba kadılıkları ise Anadolu Kazaskerliğine bağlanmıştır.

Anadolu Kazaskerliğine tâbi kazalarda görev yapan kadıların özlük işlemleri Anadolu ve Mısır Kalemi olmak üzere iki ayrı kalem tarafından yürütülmüştür. Anadolu Kalemi kazaları kendi aralarında, Mısır Kalemi kazaları da kendi aralarında belirli bir sınıflamaya tabi tutulmuştur. Bu çerçevede Safevi Devleti'nden alınan yerlerde ihdas edilen kazalar öncelikle Anadolu Kalemine bağlanmış ve her bir kazaya kadılara sağladıkları gelire göre belirli rütbeler verilmiştir. Bir ara Anadolu Kazaskerliğinde "İran Kalemi” adıyla üçüncü bir daire ihdas ve mevzubahis kazaların işlemleri buradan idare edilmişse de kısa süre sonra eski teşkilat yapısına geri dönülmüştür.

Osmanlıların İran topraklarında hüküm sürdügü on iki yıllık dönemde on üç Anadolu kazaskeri görev yapmıştır. Bu çalışmaya kaynak teşkil eden ruznamçeler ve kazaskerlerin görevde kaldıkları yıllar Tablo 1'de gösterilmiştir.

8 Osmanlı kaza teşkilatına dair ayrıntılı literatür için (bk. Yasemin Beyazıt, Osmanlı İlmiye Mesleğinde İstihdam (XVI. Yüzyll), Ankara, 2014; İsmail Gündoğdu, "The Ottoman Ulema Group and State of Practicing "Kaza" Authority During the 18th Century", (Yayımlanmamış Doktora Tezi), Orta Doğu Teknik Üniversitesi Sosyal Bilimler Enstitüsü, Ankara, 2009; Ercan Alan, "Kadıasker Ruznamçelerine Göre XVII. Yüzyılda Rumeli’de Kadılık Müessesesi”, (Yayımlanmamış Doktora Tezi), Marmara Üniversitesi Türkiyat Araştırmaları Enstitüsü, İstanbul, 2015; Levent Kuru, "Kazasker Ruznamçelerine Göre 18. Yüzyılın İlk Yarısında Rumeli'de Kadılık Müessesesi”, (Yayımlanmamış Doktora Tezi), Marmara Üniversitesi Türkiyat Araştırmaları Enstitüsü, İstanbul, 2016; Cihan Kılıç, "XVII. Yüzyılın İkinci Yarısında Osmanlı İlmiye Teşkilatında İstihdam ve Hareket (Anadolu Kadıaskerliği Örneği)", (Yayımlanmamış Doktora Tezi), Yıldırım Beyazıt Üniversitesi Sosyal Bilimler Enstitüsü, Ankara, 2017; Levent Kuru-Ahmet Önal, Osmanlı Kaza Teşkilatı (1078/1667-68), İstanbul, 2018). 
Tablo 1. 1135-1148 Tarihleri Arasında Görev Yapan Anadolu Kazaskerleri

\begin{tabular}{|l|l|l|}
\hline İsim & Görev Süresi & Ruznamçesi \\
\hline Yahyazâde Ahmed Efendi & 28 L 1135-1 L 1136 & $\begin{array}{l}\text { NO, AKR } \\
5193 / 31\end{array}$ \\
\hline Çivizâde Ataullah Efendi & 1 L 1136-1 L 1137 & $\begin{array}{l}\text { NO, AKR, } \\
5193 / 32\end{array}$ \\
\hline $\begin{array}{l}\text { Mehmed Salih Efendi (İmam } \\
\text { Sultan1, Topkapulu) }\end{array}$ & 1 L 1137-1 L 1138 & MA, AKR ${ }^{10}, 21$ \\
\hline Dürri Mehmed Efendi & 1 L 1138-1 L 1139 & MA, AKR, 22 \\
\hline Şaban Efendi & 1 L 1139-25 C 1140 & $\begin{array}{l}\text { NO, AKR, } \\
5193 / 33\end{array}$ \\
\hline Biraderzâde Mustafa Efendi & 25 C 1140-19 L 1141 & MA, AKR, 23 \\
\hline İshak Efendi & 19 L 1141-18 Ra 1143 & MA, AKR, 24 \\
\hline Zülali Hasan Efendi & 18 Ra 1143-14 Ca 1143 & $\begin{array}{l}\text { NO, AKR, } \\
5193 / 34\end{array}$ \\
\hline Mirzazâde Mehmed Salim Efendi & 14 Ca 1143-M 1144 & Tespit Edilemedi \\
\hline $\begin{array}{l}\text { Vardarizâde Şeyhzâde Mehmed } \\
\text { Efendi }\end{array}$ & M 1144-10 S 1145 & MA, AKR, 25 \\
\hline Zeynelabidin Efendi & 10 S 1145-7 Ra 1146 & $\begin{array}{l}\text { NO, AKR, } \\
5193 / 35\end{array}$ \\
\hline Pirizâde Mehmed Sahib Efendi & 7 Ra 1146-6 Ra 1147 & $\begin{array}{l}\text { NO, AKR, } \\
5193 / 36\end{array}$ \\
\hline Raşid Efendi & 6 Ra 1147-18 S 1148 & $\begin{array}{l}\text { NO, AKR, } \\
5193 / 37\end{array}$ \\
\hline
\end{tabular}

\section{İran'da Osmanlı Kaza İdaresi}

İran üzerine 1723 'te başlatılan seferde ilk askeri harekât Gürcistan topraklarındaki Tiflis Kalesi'ne yapıldı. Rusların durdurulması için hayati öneme sahip olan kalenin fethi 10 Haziran 1723'te gerçeklești. Bu tarihten birkaç gün önce de Tiflis yolu üzerindeki Gori Kalesi fethedildi. Bölgenin Osmanlı kuvvetlerinin eline geçmesiyle birlikte zaman kaybedilmeden hem askeri-idari hem de huku-

9 Nuruosmaniye Kütüphanesi (NO), Anadolu Kazasker Ruznamçesi (AKR).

10 Meşihat Arşivi (=MA), Anadolu Kazasker Ruznamçesi (=AKR). 
ki-idari teşkilatın yani kaza idaresinin oluşturulma çalışmalarıyla vergi ve toprak sisteminin belirlenmesi için tahrir işlemleri başlatıldd ${ }^{11}$.

İran'da kurulan teşkilatında mevleviyet kadılıklarının dışında kalan kasaba kadılıklarının rütbe işlemlerine dair tespit edebildiğimiz ilk belge 1 Receb 1136/26 Mart 1724 tarihlidir ${ }^{12}$. Dönemin Anadolu Kazaskeri Yahyazâde Ahmed Efendi'nin ilamı üzerine şeyhülislamın işareti ve sadrazamın buyruldusu ile Tiflis kazasına, saniye; Lori ${ }^{13}$ kazasına, hamise; Gori (Kale-i Gori) kazasına, sadise; Tiryalid ve Somhit kazalarına, sabia; Ağcakal'a, Kaygulu ve Kazak kazalarına da samine rütbeleri verildi. İlamda yer alan "kuzât dâ 'îlerinin tahtabaşıları ve sa' îr eşrâf-ı tarîk re'y ve ittifâklarıyla" ifadesi kazaların derecelendirilmesi için bir komisyonun toplandığını işaret etmektedir ${ }^{14}$.

Tiflis başta olmak üzere kurulan kazalara yapılan kadı atamalarının kayıtları incelendiğinde Tiflis kadısı Ömer Efendi'nin 29 Şaban 1136/23 Mayıs 1724'te görevinden alındığ 1 görülmektedir. Ömer Efendi’nin ne zaman atandığına dair bir bilgi Anadolu kazasker ruznamçelerine yansımamıştır. Çünkü ruznamçe kaydından Tiflis'in fetihten sonra mevleviyet kadılığı yapıldığ 1 ve Ömer'in mevali-i kiram denilen yüksek dereceli kadılardan olduğu anlaşılmaktadır. Ancak yeterli gelirinin olmamas1 sebebiyle Tiflis 1 Receb 1136/26 Mart 1724'te mevleviyet derecesinden kasaba kadılığına tenzil edilmiştir. Ömer Efendi'nin yerine de Erzincan kazasında 300 akçe ile görev yaptıktan sonra 22 aylık infisal dönemini tamamlayan Hafizzâde es-Seyyid Ebubekir, 24 aylığına 300 akçeyle Tiflis'te görevlendirilmiştir. Kazanın rütbesi de saniye olarak belirlenmiştir. Hafizâde

11 Tiflis'in fethi sonrası bu eyalet ilk olarak eski Tiflis Hanı IV. Vahtang'ın oğlu olan ve İslam'ı kabul ederek İbrahim ismini alan İbrahim Paşa'ya yurtluk-ocaklık olarak verildi (3 Zilkade 1135/5 Ağustos 1723). Bölgenin tahririne de Defterhane'den gönderilen Avni Efendi ve iki şakird 29 Şaban 1136/23 Mayıs 1724'te başladı (bk. İlker Külbilge, a.g.t., s. 113-114; Ali Sinan Bilgili, a.g.m., s. 23-62; Elvin Valiyev, a.g.t., s. 81-82; Fahamettin Başar, Osmanlı Eyâlet Tevcihâtı (1717-1730), Ankara, 1997, s. 151).

12 NO, AKR, 5193/31, vr. 1a.

13 Lori kazasının fethiyle ilgili olarak Çelebizâde İ́smail Âsım, Gence'nin fethi öncesi Erzurum Valisi Mustafa Paşa tarafından alındığı bilgisini vermiştir (bk. Râşid Mehmed Efendi-Çelebizâde İsmâil Âsım Efendi, Târîh-i Râşid ve Zeyli, haz. Abdülkadir Özcan vd., III, İstanbul, 2013, s. 1449-1450). Bu bilgiye istinaden yapılan çalışmalarda Lori'nin fethi tarihi 3 Ağustos 1725 olarak verilmiştir (İlker Külbilge, a.g.t., s. 148). Ancak Lori'de kaza teşkilatının oluşturulmasına dair belgeler ve 10 Şevval 1136/2 Temmuz 1724 tarihli mühimme kaydı buranın Tiflis'in fethi sırasında alındığını ortaya koyar (bk. NO, AKR, 5193/31, vr. 12a; A. \{DVNSMHM. d. 132, hk. 52).

14 Benzer ifade 1078 tarihinde yapılan teşkilat düzenlemesinin başında da geçmektedir (bk. Levent Kuru-Ahmet Önal, a.g.e., s. 113). 
es-Seyyid Ebubekir'den sonra da Tiflis'e kasaba kadılığ 1 statüsünde rutin atama işlemleri yapılmıştır. Tiflis Eyaleti'nde bulunan diğer kazalara da belirlenen rütbeler ile teşkilat içerisinden kadı atamaları yapılarak bölgenin kaza teşkilatı oluşturulmuştur ${ }^{15}$.

Osmanlıların Safeviler üzerine başlattıkların seferin ikinci cephesi olan Azerbaycan harekâtı iki kısma ayrılır. Bâbıâlî bir taraftan Revan ve Gence üzerinden Bakü'ye kadar olan geniş bölgeyi kontrol altına alıp Hazar Denizi’ne ulaşmayı hedeflerken diğer taraftan daha güneyden Tebriz, Urumiye, Erdebil üzerinden yine Hazar kıyılarına kadar gitmeyi amaçlamıştır ${ }^{16} .5$ Temmuz 1724 'te başlayan ve yaklaşık 3 ay süren Revan kuşatması kale müdafileriyle yapılan görüşmeler sonunda başarıyla sonuçlamış ve Revan 3 Ekim 1724'te Osmanlılara teslim olmuştur. Revan'ın fethi sonrası Nahcıvan ve Ordubad'ın alınması için harekete geçen Osmanlı kuvvetleri Ağustos'ta Nahcıvan'1, Eylül'de de Ordubad'1 ele geçirdiler ${ }^{17}$.

Bölgenin fethiyle birlikte kurulan Revan Eyaleti valiliğine 3 Kasım 1724'te Vezir Ahmed Paşa getirildi ${ }^{18}$. Ahmed Paşa'nın ilamı üzerine 20 Receb 1137/4 Nisan 1725 tarihli buyruldu ile Revan Eyaleti'nde sekiz müstakil kadılık bölgesi ihdas edildi ve Anadolu kazaskerinden vakit kaybetmeksizin bu kazalara kadı ataması yapması istendi. Kazaların rütbeleri ise Zarzebil, sadise; Saderek ma'a Vedi $^{19}$, samine; Mekû, hamise; Sürmeli ma'a Iğdır, hamise; Tesûc ${ }^{20}$, salise olarak belirlenmiştir ${ }^{21}$. Revan'dan sonra Gence'nin alınması için seraskerliğe ilk olarak Şubat 1725 'te Ahmed Paşa tayin edildi. Ancak, Bâbıâlî'nin Ahmed Paşa'nın Revan'dan ayrılmamasını daha uygun bulması üzerine May1s 1725'te Erzurum Valisi Vezir Mustafa Paşa Gence seraskeri olarak görevlendirildi. Temmuz 1725'te harekete geçen Mustafa Paşa 3 Eylül 1725'te Gence'yi kuşattı ve ertesi gün fetih gerçekleşti ${ }^{22}$.

Gence Eyaleti'nde bulunan livaların rütbelerinin tespiti ve kaza teşkilatının ihdası Evail-i Rebiülevvel 1138/7-16 Kasım 1725'te yapıldı. Bu tarihte Anadolu

15 Bu işlemlere dair atama kayıtları ektedir.

16 İlker Külbilge, a.g.t., s. 114.

17 A.g.t., s. 140 .

18 Fahamettin Başar, a.g.e., s. 163.

19 Ruznamçede Saderda ma'a Veda, Sadreda ma‘a Vedi olarak yazılmıştır.

20 Tesûc kazası için 1 Ramazan 1137/14 Mayıs 1725 'te ikinci bir ilam ve buyruldu çıkarılmıştır (bk. NO, AKR, 5193/32, vr. 4a).

21 NO, AKR, 5193/32, vr. 3 b.

22 İlker Külbilge, a.g.t., s. 148. 
kazaskerinin iki ilamı ve bu ilamlara istinaden sadrazamın iki buyruldusu vardır. İlk ilama göre, Şemseddinlü ve Halhane livaları bir kadılık bölgesi kabul edildi ve rütbesi salise olarak belirlendi. Ayrıca Bergüşad livası, rabia; Bayat livası, hamise ${ }^{23}$; Berda ve Çuvaldar livaları, sadise; Cevanşir ve Arasbâr livaları, sabia; Pesyan ve Karaçorlu livaları da samine rütbeleri ile birer kaza merkezi yapıldılar. İkinci ilama göreyse daha önce salise rütbesi verilen Şemseddinlü ve Halhane livaları, saniye rütbesine; sadise rütbesi verilen Berda kazası, salise; samine rütbesi verilen Karaçorlu livası da sabia rütbesine terfi ettirildi ${ }^{24}$.

Azerbaycan'a yönelik askeri harekâtın diğer kolu olan Tebriz'in fethi için Van Valisi Köprülüzâde Abdullah Paşa görevlendirildi. Paşa, Mayıs 1724'te öncelikle Tebriz yolu üzerindeki Cors ve Hoy'u ele geçirdi. Hoy'un güneyinde bulunan Tesûc'un ${ }^{25}$ fethi de Ağustos'ta tamamlandı. Tesûc kazasının rütbesi yukar1da belirtildiği gibi 20 Receb 1137/4 Nisan 1725 tarihli buyrulduyla salise olarak belirlenmiştir. Hoy kazasının rütbesi ise Mehmed Hamdi isimli bir kadının arzuhali üzerine 16 Ramazan 1137/29 Mayıs 1725 tarihli ilam ve buyrulduyla saniye olarak belirlenmiş ve Mehmed Hamdi, Hoy'u Cors kazası ilhakıyla 1 Ramazan 1137/14 Mayıs 1725'ten itibaren tasarruf etmeye başlamıştır ${ }^{26}$.

Nahcıvan kazası İran seferinde ordu kadısı olarak görev yapan Süleyman Efendi'nin görevlendirilmesine dair Anadolu kazaskerinin 17 Cemaziyelahir 1137/1 Şubat 1725 tarihli ilamına istinaden sitte rütbesiyle derecelendirilmiştir. 1 Receb 1137/16 Mart 1725 tarihli atama işlemiyle de Süleyman Efendi Nahcıvan kadısı olmuştur. Ayrıca Yezidabad ve Şerür kazaları Nahcıvan'a ilhak edilerek Süleyman Efendi'nin yetki sahasına dâhil edilmişler ${ }^{27}$. Tebriz civarında bulunan Tabtâb kazası da fetih sonrası Evail-i Safer 1138/9-18 Ekim 1725'te sabia rütbesiyle müstakil bir kadılık haline getirilmiştir ${ }^{28}$.

Bâbıâlî, Safeviler üzerine düzenlenen seferin üçüncü cephesine Bağdat Valisi Vezir Hasan Paşa'yı serasker tayin etmişti. Hasan Paşa, 16 Eylül 1723'te Kirmanşahan'ı almak için harekete geçti. Osmanlı ordusunun yaklaştığı haberinin Kirmanşahan'a ulaşması üzerine Vali Abdülbaki Han, Hasan Paşa'ya bir elçi göndererek aman diledi. Böylece şehir 15 Ekim 1723’te teslim alındı. Kirman-

23 Bayat livasına hamise rütbesi verilmesine rağmen ilk kadı atamasında bu kaza rabia rütbesine terfi ettirilmiştir (bk. MA, AKR, 21, vr. 9a).

24 MA, AKR, 21, vr. 3a.

25 Revan Eyaleti sınırları içinde kalmıştır.

26 NO, AKR, 5193/32, vr. 3b; NO, AKR, 5193/32, vr. 17 b.

27 NO, AKR, 5193/32, vr. 4a.

28 MA, AKR, 21, vr. 3a; 72 b. 
şahan'ın zaptından sonra Senendec (Sinne)'ten de itaat haber geldi ve 12 Kasım günü Osmanlı kuvvetleri buraya girdi ${ }^{29}$.

Kirmanşahan'ın fethi sonrası buraya ilk olarak sitte rütbesi verildi. Ezine-i Kazdağı'nda 400 akçeyle kadılık yaptıktan sonra 27 aylık infisal dönemi geçiren es-Seyyid İbrahim, 1 Safer 1137/20 Ekim 1724'te Kiramanşahan kadısı olarak atand1. Bu işleme göre İbrahim Efendi Kirmahşahan'da 1 Rebiülevvel 1137/18 Kasım 1724 'ten itibaren 499 akçe yevmiye ile 24 ay görev yapacaktı. Ancak onun vefat etmesi üzerine 7 Safer 1137/26 Ekim 1724 tarihli buyrulduyla Kirmanşahan, Hemedan $^{30}$ kazasına ilhak edildi. Böylece Hemedan kadısı Ubeydullah Efendi aynı zamanda Kirmanşahan kadısı oldu ${ }^{31}$. Bu tarihten iki hafta sonra 22 Safer 1137/10 Kasım 1724'te alınan yeni bir kararla Kirmanşahan sitte rütbesine terfi ettirilerek tekrar müstakil kadıl1k haline getirildi ve kazaya mûsıla rütbesinden munfasıl kadıların tayin edilmesi uygun görüldü ${ }^{32}$. Ancak dönemin kazasker ruznamçelerinde bu kazaya dair müstakil bir kadı ataması 1 Zilhicce 1140/9 Temmuz 1728'e kadar yoktur. Aksine bu tarihte hala Hemedan'1n ilhak1 görünmektedir ${ }^{33}$. Senendec merkezli Ardelan Eyaleti de sadise rütbesi ile tek bir kadılık haline getirildi. İhdas edilen bu kazaya, Hemedan kadısı Ubeydullah Efendi'nin arzı üzerine, 150 akçe yevmiye ile Rize'de kadılık yaptıktan sonra 28 aylık infisal dönemi geçiren Mehmed Emin 1 Receb 1138/5 Mart 1726 tarihinde tayin edildi ${ }^{34}$.

Bağdat Valisi Vezir Ahmed Paşa, 31 Ağustos 1724 tarihinde Hemedan'1 fethettikten sonra vakit kaybetmeden Eylül 1724'te Lûristan Eyaleti'nin merkezi olan Hürremabad'ı almak için harekete geçti. Ahmed Paşa'nın geldiği haberini alan ve tutunamayacağını anlayan Ali Merdan Han'ın şehri terk etmesi ve Hürremabad ileri gelenlerinin aman dilemeleriyle birlikte şehir 6 Eylül 1724'de Osmanlı kuvvetlerinin eline geçti. Hürremabad merkez olmak üzere çevresiyle birlikte Lûristan tek bir kadılık haline getirildi ve kazaya sabia rütbesi verildi. İstanbul'da Receb Paşa Medresesi'nde 40 akçe yevmiye ile müderrislik görevinden sonra otuz yıllık uzun bir infisal dönemi geçiren Hafız Ali, 1 Receb 1138/5 Mart 1726 tarihli atama işlemiyle kazanın ilk kadısı oldu ${ }^{35}$.

29 İlker Külbilge, a.g.t., s. 119-120.

30 Hemedan 31 Ağustos 1724'te fethedildi. Mevleviyet dereceli bu kazanın kadıları için (bk. Akram Nejabatı, "Osmanlı Hâkimiyetinde Hemedan (1724-1732)”, (Yayımlanmamış Doktora Tezi), Ege Üniversitesi Sosyal Bilimler Enstitüsü, İzmir, 2014, s. 129-130).

31 NO, AKR, 5193/32, vr. Kapak.

32 NO, AKR, 5193/32, vr. 1 b.

33 MA, AKR, 23, vr. 66a.

34 MA, AKR, 21, vr. 72b; MA, AKR, 21, vr. 15a.

35 MA, AKR, 21, vr. 14b, 73a. 


\section{İran Kaleminin Kurulması ve Ortaya Çıkan Sorunlar}

İran coğrafyasında fethedilen yerlerde ihdas edilen kazalar, Mart 1724'ten Haziran 1726'a kadar ki 2 y1l 2 aylık süreyi kapsayan ilk dönemde Anadolu Kazaskerliğindeki Anadolu Kalemine bağlandılar. Sadrazam Nevşehirli Damat İbrahim Paşa'nın 5 Şevval 1138/6 Haziran 1726 tarihli buyruldusuyla Anadolu Kazaskerliğinde yeni bir düzenleme yapıldı. Anadolu kazaskerine hitaben yazılan bu belgeye göre; İran coğrafyasında bulunan kazalar için tıpkı Mısır Kalemi gibi müstakil bir "İran Kalemi” kurulması için ferman-ı hümayun çıktığı, bu tarihe kadar İran'da bulunan kazalara atamaları yapılan kadıların kayıtlarının ayrılarak müstakil kalem olmak üzere başka yere kaydedilmesi ve bundan sonra yapılacak tevcih işlemlerinde kazanın rütbesiyle birlikte oluşturulan yeni deftere yazılması emredildi $^{36}$. Bu tarihten itibaren Anadolu Kazaskerliğinin yetki sahasındaki kaza ve kadıların işlemleri Anadolu, Mısır ve İran olmak üzere üç ayrı kalem tarafından yürütülmeye başlandi. Anadolu kazasker ruznamçelerindeki kayıtlar incelendiğinde, bu düzenlemenin bir neticesi olmak üzere üç kazasker döneminde “İran Kalemi” başlığı altında ruznamçelerde ayrı bir bölüm açılmış ve İran' daki kazalara yapılan atamalar bu kısma kaydedilmiştir ${ }^{37}$.

Müstakil İran Kaleminin kurulmasından sonra bölgedeki kazalarla ilgili en önemli mesele kadıların İran'da bulunan kazalardan Anadolu'daki kazalara nakil talepleridir. Kadılar sağlık, mesafe ve eşkıyalık gibi çeşitli gerekçeler öne sürerek İran'daki kazalara hiç gitmemeye ya da göreve başladıysa bir daha İran'daki kazalarda görev almamaya çalışmışlardır. Anadolu kazasker ruznamçelerinde kadıların nakil taleplerini içeren pek çok arz bulunmaktadır. Bu arzlara istinaden ç1karılan ilam ve buyruldularla uygun görülen talepler yerine getirilmiştir. Örneğin; İstanbul'da Behmen Ağa Medresesi'nde 40 akçe yevmiye ile müderrislik yaptık$\tan$ sonra 22 aylık infisal dönemi geçiren ve yapılan imtihan sonrası ilmiyenin kaza tarikine geçen Ahmed Efendi, 1 Rebiülevvel 1138/7 Kasım 1725'te Pesyan kazasına atanmıştır. Kayıtlara göre bu kazada 24 ay görev yapacak olan Ahmed, görevini daha sonra Suruc kazasından munfasıl Mustafa'ya devredecektir ${ }^{38}$. Ancak Ahmed görevinin bitmesine daha 14 ay varken Anadolu Kalemine naklini istemiştir. Ahmed'in arzuhalinden sonra Mustafa da aynı talepte bulunmuştur. Anadolu kazaskerinin 24 Muharrem 1139/21 Eylül 1726 tarihli ilamı üzerine çıkarılan iki ayrı buyrulduyla her ikisi de İran'a gitmezden evvelki rütbelerine

36 MA, AKR, 22, vr. 1b.

37 Dönemin Anadolu kazaskerleri sirasıyla; Dürri Mehmed Efendi (1 L 1138-1 L 1139/2 Haziran 1726-22 Mayıs 1727), Şaban Efendi (1 L 1139-25 C 1140/22 Mayıs 1727-7 Şubat 1728), Biraderzâde Mustafa Efendi (25 C 1140-19 L 1141/7 Şubat 1728-18 May1s 1729).

38 MA, AKR, 21, vr. 9a. 
tenzil edilerek Anadolu Kalemine nakledilmişlerdir ${ }^{39}$. Benzer şekilde Berda kazasına 1 Rebiülevvel 1138/7 Kasım 1725 tarihinde 24 aylığına atanan es-Seyyid Ahmed'in de talebine binaen 1 Rebiülahir 1139/26 Kasım 1726 tarihli Anadolu kazaskerinin ilamı ve sadrazamın buyruldusuyla Anadolu Kalemine nakli yapılmıştır ${ }^{40}$. Mekû kazasına 1 Ramazan 1137/14 Mayıs 1725'te atanan ve süresi bitmeden azlolunan Hasan İran Kaleminden Anadolu Kalemine nakledilmeyi talep etmiştir. Anadolu kazaskeri çıkardığı ilamla bu talebi sadrazama bildirmiş ve Hasan ilamda belirtildiği üzere İran'a gitmezden evvelki rütbesiyle Anadolu Kalemine naklolmuştur ${ }^{41}$.

1 Cemaziyelahir 1138/4 Şubat 1726'da Şirvan'1 mansıb kadılık olarak tasarruf etmeye başlayan Abdurrezzak'ın görev tanımı 1 Zilkade 1138/1 Temmuz 1726 'da değişmiş ve bu tarihten sonra kaza kendisine te 'bid statüyle verilmiştir. Böylece Abdurrezzak kazada süre kısıtlaması olmadan görevine devam etmiştirr $^{42}$. Şirvan'1n statüsüyle ilgili olarak yapılan bu değişiklik daha önce kazaya muvakkaten atanarak sıranın kendisine gelmesini bekleyen Abdullah'ı etkileyerek görev alamamasına neden olmuştur. Abdullah mağduriyetine istinaden sunduğu arzında talihsizliğine "bahtı siyah olunca bir adamın tûtiye dâm kursa şikârı ırâb olur" meseliyle vurgu yapmış ve şark canibine gitmek istemediğini arz etmiştir. Abdullah yine aynı arzında Anadolu'da bulunan Kazabad kazasının kendi rütbesine denk geldiğini belirterek burada görevlendirme talebinde bulunmuştur. Abdullah'ın bu isteğinden sonra dönemin Anadolu Kazaskeri Dürri Mehmed Efendi ilamla durumu sadrazama bildirmiş ve çıkan buyrulduyla Abdullah'ın Anadolu Kalemine nakli sağlanmıştır ${ }^{43}$.

Bazı durumlarda İran Kalemindeki kadılar geçici olarak Anadolu'da görev almayı talep etmişlerdir. 1 Rebiülevvel 1138/7 Kasım 1725'te Gori kazasına muvakkaten ataması yapılan Halil, bir arzuhal sunarak Gori kazasına tevkitle atandığını, göreve başlama zamanının yaklaşmasına rağmen hastalığından dolayı görev yerine gitmeye gücünün olmadığını belirtmiştir. Bu sebeple Gori’ye başka bir kadı atanıp kendisinin İstanbul'a yakın Anadolu mansıblarından birine geçici olarak tayin edilmesini talep etmiştir. Halil'in arzuhali üzerine çıkarılan ilamla mevcut rütbesiyle terfi ettirilmeden görevlendirilmesi yönünde sadrazamın onayı istenmiştir ${ }^{44}$.

39 MA, AKR, 21, vr. 72b.

40 MA, AKR, 22, vr. 3b.

41 NO, 5193/32, vr, 16b; MA, AKR, 21, vr. 5b, 35a; MA, AKR, 23, vr. 1 b.

42 MA, AKR, 21, vr. 13a; MA, AKR, 22, vr. 33b, syf. 65-66

43 MA, AKR, 22, vr. 5b.

44 MA, AKR, 22, vr. 4b. 


\section{İran Kaleminin Lağvedilmesi}

İran Kaleminin kurulmasından sonra ortaya çıkan problemler üzerine 27 Zilkade 1140/5 Temmuz 1728'de Anadolu Kazaskerliğinde yeni bir düzenlemeye gidildi. Dönemin Kazaskeri Biraderzâde Mustafa Efendi, bu tarihte çıkardığı ilamla mesafenin uzak olması sebebiyle İran canibine gidip gelmenin çok zor olduğunu, zayıf, hasta ve yaşlı kadıların yanı sıra beden kuvveti ve maddi imkânı yerinde olan kadıların dahi zorlandıklarını belirtmiştir. Mustafa Efendi ilamında, İran'daki görevleri son bulan veya azledilen kadıların mansıbdan mahrum kalıp sıkıntılar çektiklerini, İran Kaleminde görevlendirilen kadıların teşkilat içinde itibar görmediklerini, bu sebeple İran ve Anadolu Kalemlerinin eskisi gibi birleştirilip isteyen kadıların İran'daki, isteyenlerin de Anadolu'daki kazalarda görev almalarını talep etmiştir. Ayrıca Anadolu Kalemi ile İran Kaleminin birleştirilmesinden önce İran'daki kazaların rütbelerinde düzenleme yapılması gerektiği, bu değişikliklerle hem teşkilat içindeki kadıların düzenlerinin bozulmayacağı hem de zaman içinde İran'da bulunan mansıbların daha itibarlı hale geleceklerini belirtmiştir. Şeyhülislamın da işaret ve onayıyla sadrazamın buyruldusu ${ }^{45}$ üzerine iki kalem birleştirilmiştir ${ }^{46}$.

İran Kaleminin kaldırılması kararından birkaç gün sonra Anadolu kazaskeri 3 Zilhicce 1140/11 Temmuz 1728 tarihli yeni bir ilam çıkarmıştır. Buna göre; İran'da görev yapan ve bölgedeki mevcut durumdan bilgisi olan kadıların da fikir birliğiyle, İran canibindeki kazalardan on ikisinin mevcut rütbelerine uygun oldukları, diğer kazalarda rütbe tenziline ihtiyaç duyulduğu, müstakil kadılık olmayan kazaların yakınlarındaki kazalarla birleştirilerek tek bir kadılık yapılması gerektiği arz edilmiştir. Ayrıca İran kazalarının Anadolu Kalemine nakli ve rütbe düzenlemeleri için bir ferman-1 hümayun talep edilmiştir. Anadolu kazaskeri ilamına eklediği bir listeyle de rütbesi tenzil edilen ve birleştirilerek yeni rütbeleri verilen kazaları sıralamıştır. Bu liste Tablo 2'de verilmiştir.

45 Buyruldunun tarihi defterde 5 M 1140/23 Ağustos 1727 olarak yazılmıştır. Ancak ilam $27 \mathrm{Za}$ 1140/5 Temmuz 1728 tarihlidir. Dolayısıyla kâtip buyrulduya sehven 5 M 1140/23 Ağustos 1727 tarihini yazmıştır. Buyruldu 27 Za- 3 Z 1140/5-11 Temmuz 1728 arası bir tarihte çıkmış olmalıdır. Çünkü kazaskerin 3 Z 1140/11 Temmuz 1728 tarihli yeni bir ilamında bu buyrulduya atıf yapılmıştır (bk. MA, AKR, 23, vr. 2b). 
Tablo 2. İran'da Bulunan Bazı Kazalara Dair 1140 Tarihli Rütbe Düzenlemesi

\begin{tabular}{|l|c|c|}
\hline \multicolumn{1}{|c|}{ Kaza } & $\begin{array}{c}\text { Eski } \\
\text { Rütbesi }\end{array}$ & $\begin{array}{c}\text { Yeni } \\
\text { Rütbesi }\end{array}$ \\
\hline Halhane ve Şemseddin[lü] ma'a Kazak & Saniye & Sadise \\
\hline Derbend ${ }^{47}$ ma'a Arasbâr & Hamise & Samine \\
\hline Mekû ma'a Bayezid & Hamise & Sabia \\
\hline Çuvaldar ma'a Kapan & Sadise & Samine \\
\hline Berda ma'a Cevanşir & Salise & Rabia \\
\hline Tesûc & Saniye & Sadise \\
\hline Bergüşad ma'a Dizak & Rabia & Sadise \\
\hline Zarzebil ma'a Dereçiçek ve Gökçe Mezra & Sadise & Samine \\
\hline Hoy ma'a Cors ve Donboyu? & Salise & Hamise \\
\hline Pesyan ma'a Bayat & Hamise & Samine \\
\hline Tabtâb ma'a Karaçorlu & Sabia & Samine \\
\hline Tiryalid ma'a Cevased & Sadise & Sabia \\
\hline Gahyet & Saniye & Sabia \\
\hline Sultaniye ve Zencan ma`a Ehber & İlhak & Sadise \\
\hline Keltikbeyn? ma'a Karagân & İlhak & Sabia \\
\hline Astana ma'a Nahiye ve Yezabad & İlhak & Sabia \\
\hline Tefrîş ma'a Rûdbâr & Samine \\
\hline Tarum ve Halhal ma'a Mencil ve Masule ve Herzebil? & İlak \\
\hline
\end{tabular}

Tabloya göre; on üç kazanın rütbesi düşürülürken daha önce ilhak statülü on beş kaza birbirleriyle birleştirilip beş yeni müstakil kadılık kurulmuş ve uygun rütbeler verilmiştir. Yapılan düzenlemeye bakıldığında iki amaca yönelik olduğu 
görülmektedir. Kazaların mevcut rütbelerini daha alt seviyeye indirmenin hedefi özellikle teşkilata yeni giren kadıların bu kazaları tercih etmelerini sağlamaktır. İlhak kazaların birleştirilerek yeni müstakil kadılıklar yapılmasının amacı da kadılara yeni görev sahaları açmaktır. Çünkü bu dönemde teşkilattaki kadı sayısında önemli bir artışı söz konusudur. Anadolu Kazaskeri Biraderzâde Mustafa Efendi'nin ilamı sadrazam tarafından padişaha arz edilmiş, ilamdan iki gün sonra konuya dair ferman-1 hümayun çıkmıştır ${ }^{48}$.

İran Kaleminin lağvedilmesi ve rütbe düzenlemesinden sonra da bölgedeki kazaların statü ve rütbelerine dair değişikliklerin yapıldığı kayıtlara yansımıştır. Örneğin; 3 M 1141/9 Ağustos 1728 tarihli fermanla Şerür nahiyesi Revan kazasından ifraz ve Nahcıvan kazasına ilhak edilmiştir ${ }^{49}$. Gence kazası Anadolu kazaskerinin ilamı ve şeyhülislamın işaretleri üzerine 26 Rebiülahir 1141/30 Ekim 1728 tarihli buyruldu ile mevleviyet olmaktan çıkarılmış ve sitte rütbesiyle kasaba kadılığ statüsüne indirilmiştii ${ }^{50}$. Kirmanşahan kazasının müstakil kasaba kadılı̆̆ 1 statüsünden çıkarılarak Hemedan kazasının ilhakı yapılması, bu kazayı tasarruf etmek için sıranın kendisine gelmesini bekleyen Mehmed Emin Efendi'nin boşta kalmasına neden olmuştur. Mehmed Emin'in mağduriyetini arz ve Tiflis kadılığını talep etmesi üzerine 1 Muharrem 1143/17 Temmuz 1730'da Tiflis'e tayin edilmiştir ${ }^{51}$.

İran'daki Osmanlı kazalarına dair son geniş çaplı düzenleme, Anadolu Kazaskeri Sahip Mehmed Efendi'nin 21 Cemaziyelahir 1146/29 Kasım 1733 tarihli ilamı sonrası yapılmıştır. Bu ilama istinaden çıkarılan Evahir-i Cemaziyelahir 1146/29 Kasım-7 Aralık 1733 tarihli ferman-1 hümayuna göre, İran'da bulunan bazı kazalar ahalisinin perişanlığı sebebiyle müstakil kadılık yapılamamaktadır. Müstakil kazalarda ise devamlı olarak terfi ve tenzil işlemleriyle rütbe değişiklikleri yapılması teşkilat içindeki kadıların mağduriyet yaşamasına sebep olmakta, dolayısıyla İran' da bulunan kazalara kadılar gitmek istememektedir. Bu bölgedeki kazalar daha çok müderrislik yaparken kadılığa geçmek isteyenler tarafından talep edilir olmuştur. Esasen bu kimseler de kanuna aykırı bir şekilde sadise, hamise ve rabia rütbeleriyle İran kazalarına atanarak teşkilata dâhil olmakta, genellikle görevlerine gitmeyip başka yerlerde yedi sekiz ay zaman geçirdikten sonra mağduriyet gerekçesiyle Anadolu kazalarına tayin olmaya çalışmaktadırlar. Bu durum mansıb statüsündeki kaza sayısının sınırlı olmasına karşın kadı miktarının

\footnotetext{
48 MA, AKR, 23, vr. 3a.

49 MA, AKR, 23, vr. 3a.

50 MA, AKR, 23, vr. 3b.

51 MA, AKR, 24, vr. 10a, 13a, 26a.
} 
giderek arttığı XVIII. yüzyılda bir kazayı tasarruf edebilmek için uzun infisal dönemleri geçiren ve sıranın kendisine gelmesini bekleyen teşkilat içindeki kıdemli kadıları etkilemiştir. Bu çerçevede İran'da bulunan kazaların yeniden ele alınıp düzenlenmesi talebi teşkilat mensuplarından gelmiştir. Fermanla ilamda arz edildiği gibi bazı kazaların rütbeleri tenzil edilmiş, bazı kadılıkların yetki alanları değiştirilmiştir. Tablo 3'te yapılan yeni düzenleme gösterilmiştir ${ }^{52}$.

Tablo 3. 1146 Tarihli Fermana Göre Rütbe ve Statüleri Düzenlenen Kazalar

\begin{tabular}{|l|c|c|l|}
\hline \multicolumn{1}{|c|}{ Müstakil Kaza } & $\begin{array}{c}\text { Eski } \\
\text { Rütbesi }\end{array}$ & $\begin{array}{c}\text { Yeni } \\
\text { Rütbesi }\end{array}$ & \multicolumn{1}{|c|}{ İlhak Kazaları } \\
\hline Nahcivan & Saniye & Rabia & $\begin{array}{l}\text { Ordubad, Yezduvar³, Şerür, } \\
\text { Kapan }\end{array}$ \\
\hline Lori & Hamise & Hamise & $\begin{array}{l}\text { Halhane ma'a Şemseddinlü, } \\
\text { Penbe, Ağçekal'a, Kazak }\end{array}$ \\
\hline Sürmeli ma'a Igdır & Sabia & Sabia & Mekû \\
\hline Gahiyet & Samine & Sabia & Top Karaağaç \\
\hline $\begin{array}{l}\text { Kaygulu ma'a } \\
\text { Ahilkelek }\end{array}$ & Samine & Samine & \\
\hline Tiflis & Sitte & Sitte & Tiryalit, Gori, Somhit \\
\hline Gence & Mevleviyet & Mûsıla & $\begin{array}{l}\text { Bergüşad ma'a Dizak, Berda } \\
\text { ma'a Cevanşir }\end{array}$ \\
\hline
\end{tabular}

Son düzenlemeler esas alınarak hazırlanan Tablo 3 incelendiğinde, müstakil kadılık olan Nahcıvan kazasına etrafındaki bazı küçük kazalar ilhak edilmiş ve rabia rütbesi verilmiştir. Ruznamçe kayıtlarına göre fetih sonrası Nahcıvan, ilk olarak 1 Receb 1137/16 Mart 1725'te sitte rütbesiyle ihdas edilmiş ve Akşehir kadısı olmak için sırasını bekleyen Süleyman ${ }^{54} 499$ akçe yevmiye ile Nahcıvan kadıs1 olmuştur ${ }^{55}$. Sadizâde es-Seyyid Seyfullah'1n 1 Rebiülahir 1143/14 Ekim 1730 'da Nahcıvan kadısı olmasıyla kazaya Üsküdar payesi verilmiştir ${ }^{56} .1$ Şaban

52 NO, AKR, 5193/36, vr. 3a-b; Cevdet Adliye (C. ADL.) 74/4486.1.

53 Yezidabad nahiyesi ruznamçelerdeki bazı atama işlemlerinde "Yezduvar" olarak yazılmıştır. İkisi de aynı yerdir. Burası Ordubad ile Şerür arasında bir nahiyedir.

54 İran Seferi'nde ordu kadısı olarak görev yapmıştır. Kazaya atanma sebebi de budur.

55 NO, AKR, 5193/32, vr. 14a.

56 Esasen Üsküdar payesi mevleviyet seviyesidir. 
1144/29 Ocak 1732'de saniye rütbesine ${ }^{57}$ tenzil edilen Nahcivan, Evahir-i Cemaziyelahir 1146/29 Kasım-7 Aralık 1733 tarihli ferman-1 hümayunla da rabia rütbesi indirilmiştir. Böylece Nahcıvan'da 1725 ile 1733 arasında çeşitli rütbe değişimleri gerçekleşmiştir.

Fetih sonrası mevleviyet kadılığı olarak üst dereceli kazalar arasında dâhil edilen Gence, 1 Cemaziyelevvel 1141/29 Ocak 1729'da kasaba kadılı̆̆ p1larak sitte rütbesi verilmişken ${ }^{58} 1146 / 1733$ tarihli bu düzenlemeyle mûsıla rütbesine tenzil edilmiştir. Gence'ye dair dikkati çeken bir başka durum daha önce müstakil kadılık olan Bergüşad ma'a Dizak, Berda ma'a Cevanşir kazalarının Gence'nin ilhakı yapılmasıdır. Bu fermanla Tiflis kazasının rütbesinde bir değişiklik yapılmayıp Tiryalit, Gori ve Somhit kazaları Tiflis'e ilhak edilmişledir. Bu düzenlemedeki temel amaç fermanda da geçtiği üzere İran canibindeki kazaların sistemin işleyişini bozmasının önüne geçmektir. Bunun için bazı kazaların rütbeleri düşürülürken bazı kazaların sınırları genişletilerek gelirleri arttırılmıştır. Böylece bölge, teşkilat içindeki kadılar için cazip hale getirilmeye çalışılmıştır.

\section{İran'daki Osmanlı Kazalarına Yapılan Tevcîhat}

Anadolu kazasker ruznamçeleri kayıtlarına göre İran'da çeşitli rütbelerde 40 müstakil kasaba kadılığı ihdas edilmiştir. Osmanlıların bölgede hâkimiyet sürdüğü on iki yıl içinde bu kadılıklarla ilgili olarak 218 atama işlemi neticesinde 168 kadı görevlendirilmesi yapılmıştır' ${ }^{59}$. Toplam tevcihatın 160'1 mansıb, 5'i te 'bid, 2'si ilhak şeklindedir. Bir atama işleminde ise kaza mevleviyet kadılığ olarak görünmektedir. Bu kaydın kazasker ruznamçesine yansımasının sebebi ilgili kazanın kasaba kadılığına tenzil edilmesidir ${ }^{60}$. Bu verilere göre kadılıkların statülerine göre dağılımları şöyledir:

57 MA, AKR, 25, vr. 25a.

58 MA, AKR, 23, vr. 68a.

59 Ruznamçelerde bulunan atama sayısı ile görevlendirilen kadı sayısı arasındaki farkın temelde iki sebebi vardır. Birincisi, yapılan tayin sonrası çeşitli sebeplerle kadının kazayı fiili olarak tasarruf edememesi ve bir başkasının görevlendirilmesidir. İkincisi ise XVIII. yüzyılda kadı tayin işlemlerinde izlenen usulle ilgilidir. Bu dönemde kadılar öncelikle kazalara muvakkaten atanır ve kazanın sıralamasına girer daha sonra $i b k a$ işlemiyle fiili görevlendirilmeleri yapılırd. Bu prosedüre dair ayrıntılı bilgi için (bk. Levent Kuru, a.g.t., s. 115-118).

60 Osmanlı kasaba kadılıkları "mansıb", "te‘bid”, "ilhak”, "maişet” ve "arpalık” olmak üzere farklı statülerle tasarruf edilmişlerdir. Bu tür görevlendirmelere dair ayrıntılı bilgi için (bk. Levent Kuru, a.g.t., s. 80-100). 


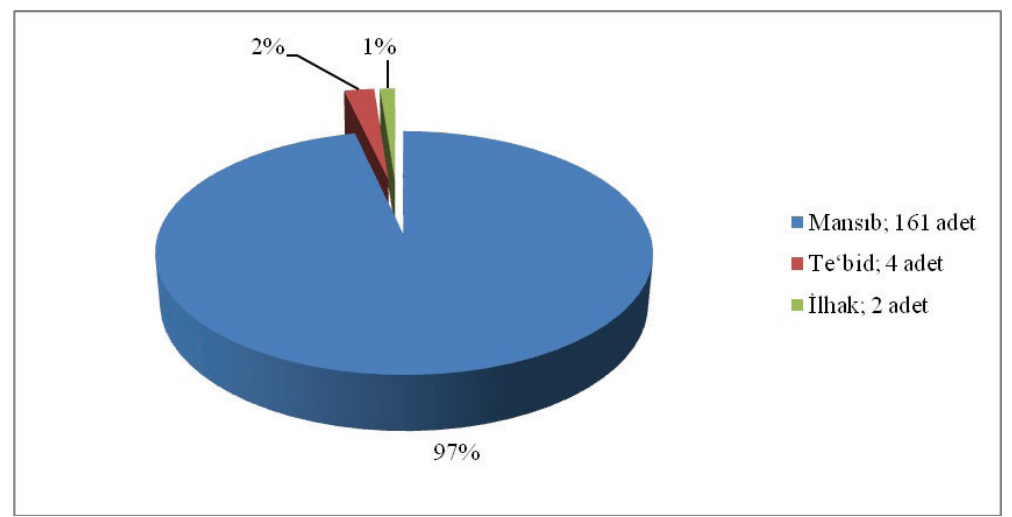

Grafik 1. İran'daki Osmanlı Kadılıklarının Statüleri

Mansıb kaza, olarak tasarruf edilen kadılıklar tüm görevlendirmelerin \%97'sini oluşturmaktır. Mansıb kaza uygulaması, kadıların kazalarda belirli sürelerle görev yaptığı, daha sonra bir başka kadı tarafından kazanın tasarruf edilmesi yani rotasyon esasına dayanır. İlk zamanlar kazaya atanan kadılar uzun süreler aynı görevde kalabilmişledir. Ancak zaman için kadıların görev süreleri kısalmıştır.

Grafiğe göre; te 'bid statüyle yapılan görevlendirmeler \%2'lik bir orana sahiptir. Bu şekildeki toplam 5 atama işleminin 3'ünde Şirvan kazasına teşkilat içindeki kadılar görevlendirilirken, 2 atama ruznamçelerde cemaat olarak tanımlanan topluluklara yapılmış ve kendi liderleri görevlendirilmiştir.

Ruznamçelerdeki 2 atama işlemi ise ilhak kazalara dairdir ve tüm atamaların \% 1'ni oluşturur. Osmanlı kaza teşkilatında bir kadılığın ilhak kaza olmasının ya da müstakil kadılık iken ilhak kaza haline getirilmesinin; kazanın baştan itibaren mahsûl-i $\mathrm{kaza}^{61}$ miktarının yeterli olmaması, boş kalması, müstakil olamayacak kadar gelirinin düşmesi veya bağlandığı kazanın mahsûl-i kaza miktarının artırılarak derecesinin yükseltilmek istenmesi gibi çeşitli sebepleri vardır. Ruznamçelerde Cevanşir ve Kirmanşahan ilhak olarak başka kazalara bağlanmışlardır. 1 Rebiülevvel 1138/7 Kasım 1725'te ihdas edilen ve müstakil kadılık yapılan Cevanşir kazası bu statüsünü 30 Receb 1141/1 Mart 1729'a kadar sürdürmüş, bu tarihten sonra Berda'nın ilhakı olmuştur. 1 Cemaziyelevvel 1142/22 Kasım

61 Osmanlı'da kazalar, kadılara sağladıkları gelirlere göre sınıflandırılma işlemine tabi tutulmuşlardır. "mahsûl-i kazâ" olarak isimlendirilen bu gelir bir yönüyle kazanın itibarî statüsünü göstermiştir. Bunun yanında kazanın büyüklüğü, önemi ve nüfus göstergeleri de derecelendirmede dikkate alınmıştır. Böylece kazaların statüleri “cihet-i kazâ” terimiyle ifade edilmiştir. Bu derecelendirilme tayin edilecek kadının kıdemiyle bağlantılı hale gelmiştir (bk. Yasemin Beyazıt, a.g.e, s. 174-177). 
1729 tarihinden itibaren de Gence'ye bağlanmıştır. 1 Safer 1137/20 Ekim 1724'te ihdas edilen Kirmanşahan ise kadısı İbrahim'in vefatı sonrası bir dönem Hemedan'a bağlanmıştır.

Kazasker ruznamçelerinde yer alan ilhak kazalarla ilgili olarak; ruznamçelerde başka bir kazaya bağlanarak müstakil olmaktan çıkarılan tüm ilhak kazalar için ayrı bir kayıt açılmamıştır. Bazı durumlarda kazanın ilhak haline geldiği bağlandığı kaza kaydından anlaşılmaktadır. Örneğin; 1 Rebiüevvel 11387 Kasım 1725 'te müstakil kadılık olarak kurulan ve mansıb kaza statüsüyle es-Seyyid Ahmed'in görevlendirildiği Berda kazasının 1 Receb 1146/8 Aralık 1733'ten sonra Gence'nin ilhakı olduğu Anadolu kazasker ruznamçelerindeki Gence'ye dair atama kayıtlarından tespit edilmektedir ${ }^{62}$. Dolayısıyla yukarıda ilhak kazalara dair verilen 2 atama işlemi ve \% 1 'lik oran, ilgili döneme ait ruznamçelerdeki müstakil işlemleri kapsamaktadır.

1723-1735 tarihleri arasında İran'da kurulan kazaların mahsûl-i kazâ miktarlarına göre itibarî statüleri incelendiğinde; 40, 100, 150, 200, 300, 400 ve 449 akçelik kadılıkların olduğu ve bu yevmiyelere uygun görevlendirmeler yapıldığı tespit edilmektedir. XVIII. yüzyılda Osmanlı kasaba kadılıklarının en düşük 150 akçe mahsûl-i kazâ ile değerlendirildiği, bu rakamın altındaki görevlendirilmelerin istisnai şartlar taşıdığ 1 bilinmektedir ${ }^{63}$. İran'daki 40 ve 100 akçe derecesindeki kadılıklar da aşağıda belirtileceği üzere istisnaî uygulamalardır. İncelenen dönemde yapılan tevcihatın yevmiyelere göre dağılımları şöyledir:

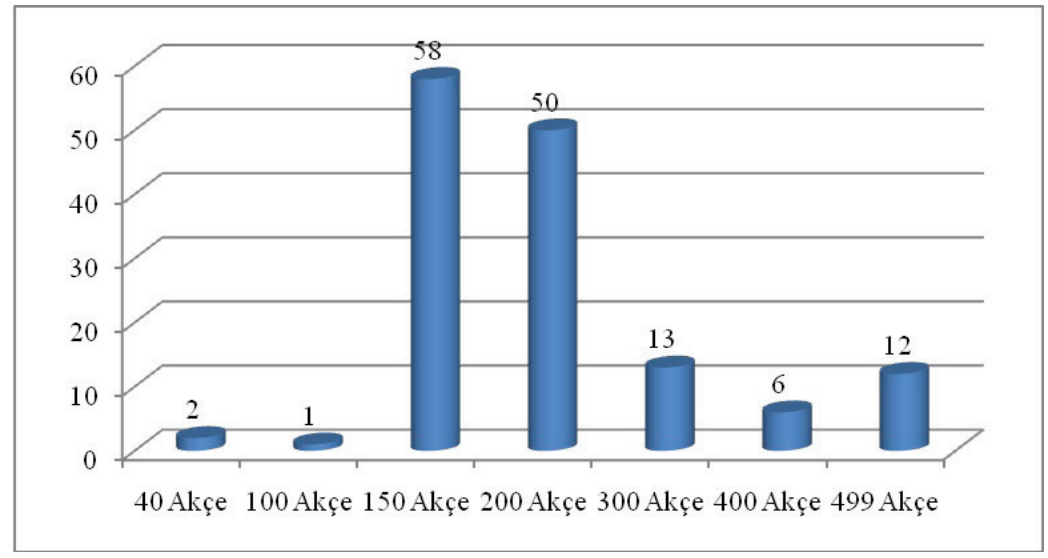

Grafik 2. Akçe Bazında Atamaların Sayısal Dağılımı

62 NO, AKR, 5193/36, vr. 12a.

63 Bu konu hakkında ayrıntılı bilgi için (bk. İsmail Gündoğdu, a.g.t., Ankara, 2009; Levent Kuru, a.g.t., İstanbul, 2016). 
Grafik 2'ye göre, İran'daki Osmanlı kazaları ağırlıklı olarak 150-200 akçelik kadılıklardır. Tüm atama kayıtları içinde üç kadı tevcihi 150 akçenin altında yapılmıştır. Yukarıda da belirtildiği gibi XVIII. yüzyıl için bu tür durumlar istisnaidir. Bu kayıtlardan biri, Şaban'ın 40 akçe yevmiye ile Çenik ma'a Meşliş’e kadı olarak tayini dairdir. Ruznamçede Çenik ve Meşliş, Tiflis Eyalet'inde bir cemaat olarak tanımlanmıştır. Bu cemaatin kendi aralarındaki davalara bakması için bir kadı ihtiyacı doğması sebebiyle yine kendi ulemalarından ve cemaatin lideri Şaban, Tiflis Valisi İshak Paşa'nın da arzıyla 1 Muharrem 1141/7 Ağustos 1728'de kadılık vazifesiyle görevlendirilmiştir. Cemaatin muhtarı yani lideri olan Şaban, kadılığ 1 te'bid statüyle tasarruf edeceği için süre kısıtlamas1 yoktur ${ }^{64}$. Benzer bir atama Mencah kadılığı için yapılmıştır. Ruznamçe kaydına göre; yine Tiflis Eyaleti'nde bir cemaat olan Mencah topluluğunun kendi aralarındaki davalara bakması için kendi ulemalarından muhtar unvanlı cemaat lideri Halil, 40 akçe yevmiye ile kadı olarak atanmıştır. Kazaya te'bid statüsü verilmiştir ${ }^{65}$.

İran'daki Osmanlı kadılıklarına 150 akçe altı yevmiye ile yapılan üçüncü ve son tayin, Meraga'ya Gümüşhaneli Mehmed'in 100 akçeyle atanmasıdır. Mehmed'in tevcih işlemi incelendiğinde kendisinin İstanbul'da bulunan 40 akçelik Manisalı Medresesi'nden munfasıl olduktan sonra ilmiyenin tedris kolundan kaza tarikine geçtiği anlaşılmaktadır. XVIII. yüzyıl için 40 akçelik medresede müderrislik görevinden sonra kadı olmak isteyen ve yapılan imtihanı geçen ilmiye mensubuna 150 akçelik kasaba kadılığı verilirdi. Bu durumda kâtibin, ilgili tayin kaydına sehven 150 yerine 100 akçe yazması muhtemeldir. Ancak İran coğrafyasının zorlu şartları, bölgenin devamlı olarak Osmanlı ve Safeviler arasında el değiştirmesi sebebiyle kazanın yeterli gelire sahip olamayacağı, bu nedenle 100 akçelik bir kadılık olarak düzenlenmiş olabileceği de ihtimal dâhilindedir. Mehmed'in tayin işleminde zikredilen Megara kazasının tekrar fethedildiği bilgisi, kazanın 100 akçelik kadılık olarak verilmiş olabileceği ihtimalini de göz ardı etmememiz gerektiğini gösterir ${ }^{66}$.

Safevilerden alınan yerlerde kurulan kazalarda en yüksek yevmiye 499 akçedir. XVIII. yüzyıl için kasaba kadılıklarının en üst basamağı olan bu kazalar, Nahcıvan, Tiflis, Urumiye, Gence ve Kirmanşahan'dır. Tiflis ve Gence, ilk kurulduklarında mevleviyet kadılığı yapılmış ancak daha sonra tenzil-i rütbeyle kasaba kadılıkları arasına dâhil edilmişlerdir ${ }^{67}$.

64 MA, AKR, 23, vr. 66b.

65 MA, AKR, 23, vr. 66a-b.

66 MA, AKR, 25, vr. 24b-25a.

67 MA, AKR, 23, vr. 68a; NO, AKR, 5193/31, vr. 12a. 
Grafik 2'nin verileri genel olarak değerlendirildiğinde; İran'da ağırlıklı olarak mahsûl-i kaza miktarı düşük kadılıkların bulunduğu, bunların akçe değerlerinin de XVIII. yüzyıl kasaba kadılıkları için belirlenen en düşük yevmiyeler olan 150-200 akçelik kazalar olduğu anlaşılmaktadır.

Kadıların görev süreleriyle ilgili olarak dönemin ruznamçe kayıtları değerlendirildiğinde; daha önce de bahsi geçtiği gibi mansıb statülü kaza görevlendirilmelerinde kadılar belli süreler için atanmışlardır. Kazasker ruznamçelerinde kadıların görev sürelerine dair ağırlıklı olarak belli bir ay belirtilmemiştir. Bunun yerine "müddet-i örfiye" ve "seneteyen" ifadeleri geçmektedir. Müddet-i örfiyenin kaç ay olduğu ile ilgili çeşitli görüşler olmakla birlikte bu süre yüzyıllar içinde değişmiştir ${ }^{68}$. XVIII. yüzyılda bu sürenin 20 ay olduğunu söylemek mümkündür. Seneteyn ise 24 aylık zaman dilimi manasına gelmektedir. 1723-1735 tarihleri arasından İran'daki Osmanlı kazalarına yapılan toplam 168 atamanın 150'sinde kadının görev süresine dair bilgi bulunur. Bu görevlendirmelerin 73 'ünde müddet-i örfiye, 61'inde ise seneteyn tabirleri kullanılmıştır. 16 atama kaydında da ay olarak kadının kazayı tasarruf süresi yazılmıştır. Osmanlı kazalarına yapılan tevcihat sonrası kadıların bir kısmının kendilerine verilen sürenin sonuna kadar görevde kalamadıkları, çeşitli sebeplerle vazifelerinin sonlandırıldığı veya kendi istekleriyle kazalarını bıraktıkları bilinmektedir. İran'daki kazalara yapılan görevlendirmelerde de süresi bitmeden mansıbından alınan veya ayrılan kadıların olduğu ruznamçelerdeki atama kayıtlarından çıkarılmaktadır.

\section{Sonuç}

Osmanlılar İran'da 1723-1735 tarihleri arasında fiili hâkimiyet kurmuşlardır. $\mathrm{Bu}$ dönem bölgede bir taraftan askeri yapılanma olan eyalet-sancak idaresi tesis edilirken diğer taraftan başında kadı unvanlı ilmiye kökenli idarecilerin olduğu kaza teşkilatı oluşturulmuştur. Mevleviyet kadılı̆̆ 1 olarak ihdas edilen Tebriz, Hemedan, Revan, Gence, Tiflis livalarından Gence ve Tiflis bir süre sonra kasaba kadılığına tenzil edilmiştir. Anadolu kazaskerinin yetkisine verilmiş olan bölgedeki kasaba kadılıklarına dair işlemler ilk etapta bu kazaskerlik bünyesindeki Anadolu Kalemi tarafından yürütülmüştür. Mart 1724'ten Haziran 1726'ya kadar süren bu süreçte İran'da yeni ihdas edilen kazalar Anadolu Kaleminde bulunan diğer kazalar gibi değerlendirilmiş ve kazalara, görevlendirilen kadılara sağladıkları gelirler göz önüne alınarak belirli rütbeler verilmiştir. İki yılı aşkın bu zaman zarfında ortaya çıkan bazı sorunlar Safevi topraklarındaki kazaların Anadolu Kaleminden ayrılması ihtiyacını doğurmuştur. Müstakil İran Kalemi 6 Haziran 
1726 tarihli kararla kurulmuştur. Bu tarihten sonra Anadolu Kazaskerliğine bağlı kasaba kadılıklarının işlemleri Anadolu, Mısır ve İran olmak üzere üç farklı kalem tarafından yürütülmüştür. İran Kaleminin ihdası sonrası bölgedeki kazaların durumu, görevlendirilen kadıların bölgeye gitmek istememeleri ya da buradaki kazaları teşkilat içinde hızlı yükselmek için bir basamak olarak kullanmaları gibi sebeplerle 5 Temmuz 1728 tarihinde yeniden değerlendirilmiş ve İran Kalemi oluşturulduktan iki yıl sonra lağvedilmiştir. Bu kaleme bağlı kazalar da tekrar Anadolu Kalemine bağlanmışlardır. Böylece bu tarihten sonra Osmanlı Devleti fiili olarak bölgeden çekilene kadar İran coğrafyasında görevlendirilen kadıların tayin-terfi işlemleri Anadolu Kalemi tarafından yürütülmüştür. 


\section{Kaynakça}

\section{Arşiv Kaynakları}

A. \{DVNSMHM. d. 132, hk.52.

Cevdet Adliye (C. ADL.) 74/4486.1.

Meşihat Arşivi, Anadolu Kazasker Ruznamçeleri (=MA, AKR), 21, 22, 23, 24,25 .

Nuruosmaniye Kütüphanesi Anadolu Kazasker Ruznamçeleri (=NO, AKR), Eski Kay1t, 5193/31, 5193/32, 5193/33, 5193/34, 5193/35, 5193/36, 5193/37.

\section{Araştırma Eserleri}

Alan, Ercan, "Kadıasker Ruznamçelerine Göre XVII. Yüzyılda Rumeli'de Kadılık Müessesesi”, (Yayımlanmamış Doktora Tezi), Marmara Üniversitesi Türkiyat Araştırmaları Enstitüsü, İstanbul, 2015.

Başar, Fahamettin, Osmanlı Eyâlet Tevcihâtı (1717-1730), Ankara, 1997.

Beyazıt, Yasemin, Osmanlı İlmiye Mesleğinde İstihdam (XVI. Yüzyıl), Ankara, 2014.

Bilgili, Ali Sinan, "Osmanlı ve Safevi Hâkimiyetlerinde Tiflis (XVIII. Yüzy1l)”, Türk Kültürü İncelemeleri Dergisi, 21, İstanbul, 2009.

Gündoğdu, İsmail, "The Ottoman Ulema Group and State of Practicing "Kaza" Authority During the 18th Century", (Yayımlanmamış Doktora Tezi), Orta Doğu Teknik Üniversitesi Sosyal Bilimler Enstitüsü, Ankara, 2009.

Ilgaz, Selçuk, “Osmanlı Hâkimiyetinde Revan (Çukur Sa'ad) (XVI.-XVIII. Yüzyıllar Arasında Sosyo-Ekonomik Tarih)", (Yayımlanmamış Doktora Tezi), Atatürk Üniversitesi Sosyal Bilimler Enstitüsü, Erzurum, 2010.

Işık, Rukiye, "Osmanl1-İran Seferlerinin Lojistik Hazırlıkları (1630-1750)", (Yayımlanmamış Yüksek Lisans Tezi), Cumhuriyet Üniversitesi Sosyal Bilimler Enstitüsü, Sivas, 2011.

İvecan, Raif, "Osmanlı Hâkimiyetinde Revan (1724-1746)", (Yayımlanmamış Doktora Tezi), Marmara Üniversitesi Türkiyat Araştırmaları Enstitüsü, İstanbul, 2007.

Kılıç, Cihan, "XVII. Yüzyılın İkinci Yarısında Osmanlı İlmiye Teşkilatında İstihdam ve Hareket (Anadolu Kadıaskerliği Örneği)", (Yayımlanmamış Doktora Tezi), Yıldırım Beyazıt Üniversitesi Sosyal Bilimler Enstitüsü, Ankara, 2017. 
Köse, Osman, "XVIII. Yüzyılda Osmanl1-Rus Münasebetleri”, Osmanl, I, Ankara, 1999.

Kurtaran, Uğur, "Sultan Birinci Mahmud ve Dönemi (1730-1754)", (Yayımlanmamış Doktora Tezi), Selçuk Üniversitesi Sosyal Bilimler Enstitüsü, Konya, 2012.

Kuru, Levent - Önal, Ahmet, Osmanlı Kaza Teşkilatı (1078/1667-68), İstanbul, 2018.

Kuru, Levent, "Kazasker Ruznamçelerine Göre 18. Yüzyılın İlk Yarısında Rumeli'de Kadılık Müessesesi”, (Yayımlanmamış Doktora Tezi), Marmara Üniversitesi Türkiyat Araştırmaları Enstitüsü, İstanbul, 2016.

Külbilge, İlker, "18. Yüzyılın İlk Yarısında Osmanlı İran Siyasi İlişkileri (1703-1747)", (Yayımlanmamış Doktora Tezi), Ege Üniversitesi Sosyal Bilimler Enstitüsü, İzmir, 2010.

Nejabatı, Akram, "Osmanlı Hâkimiyetinde Hemedan (1724-1732)", (Yayımlanmamış Doktora Tezi), Ege Üniversitesi Sosyal Bilimler Enstitüsü, İzmir, 2014.

Râşid Mehmed Efendi - Çelebizâde İsmâil Âsım Efendi, Târîh-i Râşid ve Zeyli, haz. Abdülkadir Özcan vd., III, İstanbul, 2013.

Teyyüboğlu, Mustafazade Tevfik, “XVIII. Yüzyılın İlk Yarısında Kafkaslarda Osmanlı-Rus İlişkileri”, Osmanlı, I, Ankara, 1999.

Uzunçarşı1l, İsmail Hakk1, Osmanlı Tarihi, VI, Ankara 1988.

Valiyev, Elvin, "XVIII. Yüzyılın İlk Yarısında Güney Kafkasya: Osmanl1, Safevi ve Rusya Kıskacında”, (Yayımlanmamış Yüksek Lisans Tezi), Selçuk Üniversitesi Sosyal Bilimler Enstitüsü, Konya, 2014.

Valiyev, Elvin - Yörük, Doğan, "Güney Kafkasya'da Osmanlı Hâkimiyeti (1723-1735)”, Selçuk Üniversitesi Türkiyat Araştırmaları Enstitüsü Dergisi (SUTAD), S. 40, 2016.

Yetiş, İbrahim, “Osmanlı İran Savaşları (1722-1746)”, (Yayımlanmamış Yüksek Lisans Tezi), Muğla Sitkı Koçman Üniversitesi Sosyal Bilimler Enstitüsü, Muğla, 2014.

Yıldırım, Alper, “I. Mahmud Devri Osmanlı İran İlişskileri”, (Yayımlanmamış Yüksek Lisans Tezi), Osmangazi Üniversitesi Sosyal Bilimler Enstitüsü, Eskişehir, 2017. 
Ek: 1723-1735 Arası İran'daki Osmanlı Kazalarına Yapılan Kadı Tevcihatı $(1723-1735)^{69}$

\begin{tabular}{|c|c|c|c|c|c|c|c|c|c|}
\hline Kaza & Kadı İsmi & $\begin{array}{c}\text { Göreve } \\
\text { Başlama } \\
\text { Tarihi }\end{array}$ & $\begin{array}{c}\text { Tevcih } \\
\text { Şekli }\end{array}$ & $\begin{array}{c}\text { Ayrılma } \\
\text { Tarihi }\end{array}$ & $\begin{array}{c}\text { Atandığ } \mathbf{I} \\
\text { Derece }\end{array}$ & $\begin{array}{c}\text { Görev } \\
\text { Bitiş } \\
\text { Sebebi }\end{array}$ & $\begin{array}{l}\text { Kazanın } \\
\text { Rütbesi }\end{array}$ & $\begin{array}{l}\text { İlhak } \\
\text { Kazası }\end{array}$ & $\begin{array}{c}\text { Başka } \\
\text { Kazada } \\
\text { Görev } \\
\text { Süresi } \\
\text { (Ay) }\end{array}$ \\
\hline Ağcakal'a & $\begin{array}{l}\text { Mehmed } \\
\text { Emin }\end{array}$ & $1 \mathrm{~N} 1136$ & K & $29 \mathrm{R} 1138$ & 150 & Ref & $\begin{array}{c}\text { Samine } \\
\text { ve } \\
\text { Sabia }\end{array}$ & & \\
\hline Ağcakal'a & Hüseyin & $1 \mathrm{Ca} 1138$ & K & $30 \mathrm{Za} 1139^{*}$ & 150 & & Sabia & & \\
\hline Ağcakal'a & Yusuf & $1 \mathrm{Z} 1139 *$ & K & $1 \mathrm{Ra} 1141$ & 150 & $\begin{array}{c}\text { Bi-Berat } \\
\text { Terk }\end{array}$ & Sadise & & \\
\hline Ağcakal‘a & Mehmed & $1 \mathrm{Ra} 1141$ & K & $29 \mathrm{~S} 1142 *$ & 150 & & & & 8 \\
\hline Ağcakal‘a & Süleyman & $1 \operatorname{Ra} 1142 *$ & K & $29 \mathrm{~S} 1143 *$ & & & & & \\
\hline Ağcakal'a & İsmail & $1 \mathrm{Ra} 1143 *$ & K & 29 L $1144 *$ & 150 & & & & \\
\hline Ağcakal'a & Ali & $1 \mathrm{Za} 1144 *$ & K & $30 \mathrm{Za} 1145$ & & Ref & & & \\
\hline Ağcakal'a & Salih & $1 \mathrm{Z} 1145$ & K & $30 \mathrm{Za} 1146 *$ & 150 & & & & 8 \\
\hline Arasbâr & $\begin{array}{l}\text { el-Hac } \\
\text { Mehmed }\end{array}$ & $1 \mathrm{Ra} 1138$ & K & $30 \mathrm{Za} 1139 *$ & 150 & & Sabia & & \\
\hline Arasbâr & Mehmed & $1 \mathrm{Z} 1139 *$ & K & 29 C 1141 * & 150 & & Sabia & & \\
\hline Arasbâr & Mustafa & 1 B 1141 & K & $29 \mathrm{~S} 1143 *$ & 150 & & Samine & Derbend & \\
\hline $\begin{array}{l}\text { Ardelan } \\
\text { ma'a } \\
\text { Senendec }\end{array}$ & $\begin{array}{l}\text { Mehmed } \\
\text { Emin }\end{array}$ & $1 \mathrm{Ra} 1139$ & K & $1 \mathrm{C} 1140$ & 200 & Nakl & Sadise & & \\
\hline
\end{tabular}

69 Tablodaki verileri değerlendirirken aşağıdaki açıklamalara dikkat edilmelidir.

1. Tablo'daki veriler MA, AKR, 21, 22, 23, 24, 25 ve NO, AKR, Eski Kayit, 5193/31, 5193/32, 5193/33, 5193/34, 5193/35, 5193/36, 5193/37'den çıkarılmıştır.

2. "Tevcih şekli başlıklı" sütun kazaların tasarruf şeklini göstermektedir. Buna göre; $\mathrm{K}=$ Mansıb kadılık; T= Te‘bid kadılık, $\dot{\mathrm{I}}=$ ilhak.

3. Ruznamçelerdeki veri eksikliklerinden atama işlemi yapılan kadıların bazılarının göreve başlama ve görevden ayrılma tarihlerini kesin olarak tespit etmek mümkün değildir. $\mathrm{Bu}$ durumda olan ve netlik arz etmeyen tarihlerin yanına * işareti konulmuştur. 


\begin{tabular}{|c|c|c|c|c|c|c|c|c|c|}
\hline Kaza & Kadı İsmi & $\begin{array}{c}\text { Göreve } \\
\text { Başlama } \\
\text { Tarihi }\end{array}$ & $\begin{array}{c}\text { Tevcih } \\
\text { Şekli }\end{array}$ & $\begin{array}{c}\text { Ayrılma } \\
\text { Tarihi }\end{array}$ & $\begin{array}{c}\text { Atandığ } \mathbf{I} \\
\text { Derece }\end{array}$ & $\begin{array}{c}\text { Görev } \\
\text { Bitiş } \\
\text { Sebebi }\end{array}$ & $\begin{array}{l}\text { Kazanın } \\
\text { Rütbesi }\end{array}$ & $\begin{array}{l}\text { İlhak } \\
\text { Kazası }\end{array}$ & $\begin{array}{c}\text { Başka } \\
\text { Kazada } \\
\text { Görev } \\
\text { Süresi } \\
\text { (Ay) }\end{array}$ \\
\hline $\begin{array}{l}\text { Ardelan } \\
\text { ma'a } \\
\text { Senendec }\end{array}$ & $\begin{array}{l}\text { Ahmed } \\
\text { Reşid }\end{array}$ & $1 \mathrm{~B} 1140$ & K & $30 \mathrm{Za} 1141$ & 150 & Azl & $\begin{array}{c}\text { Sadise ve } \\
\text { Hamise }\end{array}$ & & \\
\hline $\begin{array}{l}\text { Ardelan } \\
\text { ma'a } \\
\text { Senendec }\end{array}$ & Ömer & $1 \mathrm{Z} 1141$ & K & $30 \mathrm{Za} 1143 *$ & 200 & & Hamise & & \\
\hline Bayat & $\begin{array}{l}\text { Ekmelzâde } \\
\text { es-Seyyid } \\
\text { Hasan }\end{array}$ & $1 \mathrm{Ra} 1138$ & K & $29 \mathrm{~S} 1140 *$ & 200 & & Rabia & $?$ & \\
\hline Berda & $\begin{array}{l}\text { es-Seyyid } \\
\text { Ahmed }\end{array}$ & $1 \mathrm{Ra} 1138$ & K & $29 \mathrm{~S} 1140 *$ & 300 & & Salise & & \\
\hline Berda & Hasan & $1 \mathrm{Ra} 1140 *$ & K & $1 \mathrm{C} 1141$ & 300 & Vefat & Salise & & \\
\hline Berda & $\begin{array}{l}\text { es-Seyyid } \\
\text { Sunullah }\end{array}$ & 1 Ş 1141 & K & 29 C 1143 & 200 & Ref & Rabia & $\begin{array}{c}\text { Cevanşir } \\
\text { ve Otuziki } \\
\text { ve Banara }\end{array}$ & \\
\hline Berda & $\begin{array}{l}\text { Hafiz } \\
\text { Mustafa }\end{array}$ & $1 \mathrm{~B} 1143$ & K & $30 \mathrm{Ca} 1144$ & 200 & Ref & & $\begin{array}{c}\text { Cevanşir } \\
\text { ve Otuziki } \\
\text { ve Banara }\end{array}$ & \\
\hline Berda & $\begin{array}{l}\text { Derviş } \\
\text { Hasan }\end{array}$ & $1 \mathrm{C} 1144$ & K & 29 Ş 1145 & & Ref & & $\begin{array}{c}\text { Cevanşir } \\
\text { ve Otuziki } \\
\text { ve Banara }\end{array}$ & \\
\hline Berda & Süleyman & $1 \mathrm{~N} 1145$ & K & 29 Ş $1146^{*}$ & 300 & & & $\begin{array}{c}\text { Cevanşir } \\
\text { ve Otuziki } \\
\text { ve Banara }\end{array}$ & 8 \\
\hline Bergüşad & $\begin{array}{l}\text { Abdulvah- } \\
\text { hab }\end{array}$ & $1 \mathrm{Ca} 1138$ & K & 30 M 1139 & 200 & Vefat & Rabia & & \\
\hline Bergüşad & Mehmed & $1 \mathrm{~S} 1139$ & K & 30 M 1141 & 200 & Ref & Salise & & \\
\hline Bergüşad & Mustafa & $1 \mathrm{~S} 1141$ & K & 29 L 1142 & 200 & Ref & Sadise & Dizak & \\
\hline Bergüşad & Mehmed & $1 \mathrm{Za} 1142$ & K & 29 Ş 1144 * & 200 & & Rabia & Dizak & \\
\hline Bergüşad & Ahmed & $1 \mathrm{~N} 1144$ & K & 29 Ş $1145 *$ & 200 & & Sadise & & \\
\hline
\end{tabular}




\begin{tabular}{|c|c|c|c|c|c|c|c|c|c|}
\hline Kaza & Kadı İsmi & $\begin{array}{c}\text { Göreve } \\
\text { Başlama } \\
\text { Tarihi }\end{array}$ & $\begin{array}{l}\text { Tevcih } \\
\text { Şekli }\end{array}$ & $\begin{array}{c}\text { Ayrılma } \\
\text { Tarihi }\end{array}$ & $\begin{array}{c}\text { Atandığg } \\
\text { Derece }\end{array}$ & \begin{tabular}{|c|} 
Görev \\
Bitiş \\
Sebebi
\end{tabular} & $\begin{array}{c}\text { Kazanın } \\
\text { Rütbesi }\end{array}$ & $\begin{array}{l}\text { İlhak } \\
\text { Kazası }\end{array}$ & $\begin{array}{c}\text { Başka } \\
\text { Kazada } \\
\text { Görev } \\
\text { Süresi } \\
\text { (Ay) }\end{array}$ \\
\hline Cevanşir & $\begin{array}{l}\text { Makbul- } \\
\text { zâde Şeyh } \\
\text { İbrahim }\end{array}$ & $1 \mathrm{Ra} 1138$ & K & $29 \mathrm{~S} 1140$ & 200 & Ref & Sabia & & \\
\hline Cevanşir & Halil & $1 \mathrm{Ra} 1140$ & K & 30 B 1141 & 200 & $\begin{array}{c}\text { Bi-Berat } \\
\text { Ref }\end{array}$ & & $\begin{array}{c}\text { Otuziki ve } \\
\text { Banara }\end{array}$ & \\
\hline Cevanşir & $\begin{array}{l}\text { Vakuri } \\
\text { Abdullah }\end{array}$ & $1 \mathrm{~B} 1141$ & $\dot{I}$ & 29 R 1142 & & Ref & & $\mid \begin{array}{c}\text { Şeki ve } \\
\text { Derende } \\
{[\text { Derbend }]}\end{array}$ & \\
\hline $\begin{array}{l}\text { Çenik } \\
\text { ma‘a } \\
\text { Meşliş } \\
\text { Cemaati }\end{array}$ & \begin{tabular}{|l|} 
Şaban \\
{$[$ Cemaatin } \\
lideri $]$
\end{tabular} & $1 \mathrm{M} 1141$ & $\mathrm{~T}$ & & 40 & & & & \\
\hline Çuvaldar & $\begin{array}{l}\text { es-Seyyid } \\
\text { Şeyh Ali }\end{array}$ & $1 \mathrm{Ra} 1138$ & K & $29 \mathrm{~S} 1140 *$ & 200 & & Sadise & ? & \\
\hline Çuvaldar & $\begin{array}{l}\text { Hatibzâde } \\
\text { Mehmed }\end{array}$ & $1 \operatorname{Ra} 1140 *$ & K & 29 L $1141 *$ & 200 & & Sadise & ? & \\
\hline $\begin{array}{l}\text { Dereçiçek } \\
\text { ve Gökçe } \\
\text { ve Mezra'a } \\
\text { nahiyeleri }\end{array}$ & $\begin{array}{l}\text { es-Seyyid } \\
\text { Mustafa }\end{array}$ & $1 \mathrm{M} 1139$ & K & 29 Z 1140 * & 150 & & Sabia & & \\
\hline $\begin{array}{l}\text { Dereçiçek } \\
\text { ve Gökçe } \\
\text { ve Mezra'a } \\
\text { nahiyeleri }\end{array}$ & Mehmed & $1 \mathrm{M} 1141$ & K & 29 C 1141 & 150 & Terk & & Raresil & \\
\hline $\begin{array}{l}\text { Dereçiçek } \\
\text { ve Gökçe } \\
\text { ve Mezra'a } \\
\text { nahiyeleri }\end{array}$ & Süleyman & 1 B 1141 & K & $29 \mathrm{~S} 1142$ & 150 & Ref & & Raresil & \\
\hline $\begin{array}{l}\text { Dereçiçek } \\
\text { ve Gökçe } \\
\text { ve Mezra'a } \\
\text { nahiyeleri }\end{array}$ & $\begin{array}{l}\text { Hafız } \\
\text { Mehmed } \\
\text { Salih }\end{array}$ & $1 \mathrm{Ra} 1142$ & K & 29 L 1143 * & 150 & & & Raresil & \\
\hline Gahyet & Mehmed & & K & 29 Ş 1141 & & Ref & Sabia & & \\
\hline
\end{tabular}




\begin{tabular}{|c|c|c|c|c|c|c|c|c|c|}
\hline Kaza & Kadı İsmi & $\begin{array}{c}\text { Göreve } \\
\text { Başlama } \\
\text { Tarihi }\end{array}$ & $\begin{array}{c}\text { Tevcih } \\
\text { Şekli }\end{array}$ & $\begin{array}{c}\text { Ayrilma } \\
\text { Tarihi }\end{array}$ & $\begin{array}{c}\text { Atandığı } \\
\text { Derece }\end{array}$ & $\begin{array}{l}\text { Görev } \\
\text { Bitiş } \\
\text { Sebebi }\end{array}$ & $\begin{array}{l}\text { Kazanın } \\
\text { Rütbesi }\end{array}$ & $\begin{array}{l}\text { İlhak } \\
\text { Kazası }\end{array}$ & \begin{tabular}{|c} 
Başka \\
Kazada \\
Görev \\
Süresi \\
(Ay)
\end{tabular} \\
\hline Gahyet & $\begin{array}{l}\text { es-Seyyid } \\
\text { Mehmed } \\
\text { Said }\end{array}$ & $1 \mathrm{~N} 1141$ & K & $30 \mathrm{~N} 1142$ & 150 & Ref & Sabia & & \\
\hline Gahyet & $\begin{array}{l}\text { es-Seyyid } \\
\text { Mehmed }\end{array}$ & $1 \mathrm{~L} 1142$ & K & 29 Z 1143 * & & & & & \\
\hline Gahyet & Ahmed & $1 \mathrm{M} 1144$ * & K & $29 \mathrm{R} 1145$ & & Ref & & & \\
\hline Gahyet & $\begin{array}{l}\text { Abdurrah- } \\
\text { man }\end{array}$ & $1 \mathrm{Ca} 1145$ & K & 30 M 1146 & & Ref & Samine & & \\
\hline Gahyet & $\begin{array}{l}\text { es-Seyyid } \\
\text { İbrahim }\end{array}$ & $1 \mathrm{Ra} 1146$ & K & $30 \mathrm{~N} 1147$ * & 150 & & Sabia & $\begin{array}{c}\text { Tobkaraa- } \\
\text { ğacı }\end{array}$ & \\
\hline Gahyet & Hasan & $1 \mathrm{~L} 1147 *$ & K & $30 \mathrm{Ca} 1149 *$ & 150 & & & $\begin{array}{c}\text { Tobkaraa- } \\
\text { ğacı }\end{array}$ & \\
\hline Gence & $\begin{array}{l}\text { Vakuri } \\
\text { Abdullah }\end{array}$ & $1 \mathrm{C} 1141$ & K & 1 B 1142 & 499 & Vefat & Sitte & $\begin{array}{c}\text { Kara- } \\
\text { bağ ve } \\
\text { Şemsed- } \\
\text { dinlü ve } \\
\text { Halhane } \\
\text { ve Çuval- } \\
\text { dar ma'a } \\
\text { Kapan }\end{array}$ & \\
\hline Gence & Mehmed & $1 \mathrm{~B} 1142$ & K & 29 C 1144 * & & & Siite & $\begin{array}{c}\text { Kara- } \\
\text { bağ ve } \\
\text { Şemsed- } \\
\text { dinlü ve } \\
\text { Halhane } \\
\text { ve Çuval- } \\
\text { dar ma'a } \\
\text { Kapan }\end{array}$ & \\
\hline Gence & $\begin{array}{l}\text { Şeyh } \\
\text { Mehmed } \\
\text { Nekari }\end{array}$ & $1 \mathrm{~L} 1146$ & K & $30 \mathrm{Ca} 1148 *$ & 400 & & Mûsıla & $\begin{array}{c}\text { Bergüşad } \\
\text { ma'a } \\
\text { Dizak ve } \\
\text { Berda ve } \\
\text { Cevanşir }\end{array}$ & \\
\hline
\end{tabular}




\begin{tabular}{|c|c|c|c|c|c|c|c|c|c|}
\hline Kaza & Kadı İsmi & $\begin{array}{c}\text { Göreve } \\
\text { Başlama } \\
\text { Tarihi }\end{array}$ & $\begin{array}{c}\text { Tevcih } \\
\text { Şekli }\end{array}$ & $\begin{array}{c}\text { Ayrılma } \\
\text { Tarihi }\end{array}$ & $\begin{array}{c}\text { Atandığı } \\
\text { Derece }\end{array}$ & \begin{tabular}{|c} 
Görev \\
Bitiş \\
Sebebi
\end{tabular} & $\begin{array}{l}\text { Kazanın } \\
\text { Rütbesi }\end{array}$ & $\begin{array}{l}\text { İlhak } \\
\text { Kazası }\end{array}$ & $\begin{array}{c}\text { Başka } \\
\text { Kazada } \\
\text { Görev } \\
\text { Süresi } \\
\text { (Ay) }\end{array}$ \\
\hline Gence & Mehmed & $1 \mathrm{C} 1148 *$ & K & 30 M $1150 *$ & 400 & & Mûsıla & $\begin{array}{c}\text { Bergüşad } \\
\text { ma'a } \\
\text { Dizak ve } \\
\text { Berda ve } \\
\text { Cevanşir }\end{array}$ & \\
\hline Gori & $\begin{array}{l}\text { Tuğcizâde } \\
\text { Mustafa }\end{array}$ & $1 \mathrm{~N} 1136$ & K & $29 \mathrm{R} 1138$ & 200 & Ref & Sadise & & \\
\hline Gori & Ali & $1 \mathrm{Ca} 1138$ & K & $29 \mathrm{R} 1139$ & 150 & Ref & & & 10 \\
\hline Gori & Mehmed & $1 \mathrm{Ca} 1139$ & K & 29 L 1140 & 200 & Ref & Hamise & & \\
\hline Gori & Mustafa & $1 \mathrm{Z} 1140$ & K & 30 B $1142 *$ & 300 & & Sadise & $\begin{array}{c}\text { Mehran } \\
\text { nahiyesi }\end{array}$ & \\
\hline Gori & Mehmed & 1 Ş $1142 *$ & K & 30 Ra $1144 *$ & 200 & & Sadise & & \\
\hline Hoy & $\begin{array}{l}\text { Mehmed } \\
\text { Hamdi }\end{array}$ & $1 \mathrm{~L} 1137$ & K & 30 B 1139 & 400 & Ref & Saniye & Cors & \\
\hline Hoy & $\begin{array}{l}\text { es-Seyyid } \\
\text { Ahmed }\end{array}$ & 1 Ş 1139 & K & $30 \mathrm{Ra} 1141$ & 300 & Ref & Hamise & $\begin{array}{c}\text { Cors, } \\
\text { Donbeli }\end{array}$ & \\
\hline Hoy & Abdulnebi & $1 \mathrm{R} 1141$ & K & $30 \mathrm{Ra} 1143$ & 200 & Vefat & Hamise & $\begin{array}{c}\text { Cors, } \\
\text { Donbeli }\end{array}$ & \\
\hline Hoy & $\begin{array}{l}\text { es-Seyyid } \\
\text { Ali }\end{array}$ & $1 \mathrm{M} 1143$ & K & 29 Ş $1144 *$ & 200 & & & $\begin{array}{c}\text { Cors, } \\
\text { Donbeli }\end{array}$ & \\
\hline Hoy & $\begin{array}{l}\text { Ezber- } \\
\text { cizâde } \\
\text { Mustafa }\end{array}$ & $1 \mathrm{~N} 1144$ & K & $29 \mathrm{R} 1146 *$ & 200 & & Rabia & Cors & \\
\hline Karaçorlu & $\begin{array}{l}\text { Altıpar- } \\
\text { makzâde } \\
\text { Mehmed }\end{array}$ & $1 \mathrm{Ra} 1138$ & K & $29 \mathrm{~S} 1140 *$ & 150 & & Sabia & $?$ & \\
\hline Karaçorlu & $\begin{array}{l}\text { Abdülke- } \\
\text { rim }\end{array}$ & $1 \operatorname{Ra} 1140 *$ & K & 29 L $1141 *$ & 150 & & Sadise & & \\
\hline Kaygulu & $\begin{array}{l}\text { Ezber- } \\
\text { cizâde } \\
\text { Mustafa }\end{array}$ & $1 \mathrm{~N} 1136$ & $\mathrm{~K}$ & $30 \mathrm{Ra} 1138$ & 150 & Ref & Samine & Ahilkelek & \\
\hline
\end{tabular}




\begin{tabular}{|c|c|c|c|c|c|c|c|c|c|}
\hline Kaza & Kadı İsmi & $\begin{array}{c}\text { Göreve } \\
\text { Başlama } \\
\text { Tarihi }\end{array}$ & $\begin{array}{c}\text { Tevcih } \\
\text { Şekli }\end{array}$ & $\begin{array}{c}\text { Ayrılma } \\
\text { Tarihi }\end{array}$ & $\begin{array}{c}\text { Atandığı } \\
\text { Derece }\end{array}$ & $\begin{array}{c}\text { Görev } \\
\text { Bitiş } \\
\text { Sebebi }\end{array}$ & $\begin{array}{l}\text { Kazanın } \\
\text { Rütbesi }\end{array}$ & $\begin{array}{c}\text { İlhak } \\
\text { Kazası }\end{array}$ & $\begin{array}{c}\text { Başka } \\
\text { Kazada } \\
\text { Görev } \\
\text { Süresi } \\
\text { (Ay) }\end{array}$ \\
\hline Kaygulu & Ömer & $1 \mathrm{R} 1138$ & K & 30 B 1139 & 150 & Ref & & Ahilkelek & \\
\hline Kaygulu & Hüseyin & 1 Ş 1139 & K & $30 \mathrm{Ca} 1141$ & 150 & Ref & & Ahilkelek & \\
\hline Kaygulu & Mehmed & $1 \mathrm{C} 1141$ & K & $30 \mathrm{Z} 1142$ & 150 & Terk & & Ahilkelek & \\
\hline Kaygulu & Mehmed & $1 \mathrm{M} 1143$ & K & 29 Ş 1144 * & 150 & & Samine & Ahilkelek & \\
\hline Kaygulu & $\begin{array}{l}\text { es-Seyyid } \\
\text { Ali }\end{array}$ & $1 \mathrm{~L} 1146$ & $\mathrm{~K}$ & $29 \mathrm{~S} 1148$ & 150 & Ref & Samine & Ahilkelek & \\
\hline Kaygulu & $\begin{array}{l}\text { Şeyh } \\
\text { Osman }\end{array}$ & $1 \mathrm{Ra} 1148$ & K & 30 Z 1148 * & 150 & & & Ahilkelek & 10 \\
\hline Kaygulu & Salih & $1 \mathrm{M} 1149$ * & K & 29 L $1149 *$ & 150 & & & Ahilkelek & 10 \\
\hline Kaygulu & Hüseyin & $1 \mathrm{Za} 1149 *$ & K & 29 C $1151 *$ & 150 & & & Ahilkelek & \\
\hline Kazak & $\begin{array}{l}\text { es-Seyyid } \\
\text { Mehmed }\end{array}$ & $1 \mathrm{~N} 1136$ & K & $29 \mathrm{~S} 1138$ & 150 & Ref & Samine & & \\
\hline Kazak & Mustafa & $1 \mathrm{Ra} 1138$ & K & 29 L 1139 & 150 & Ref & & & \\
\hline Kazak & Mustafa & $1 \mathrm{Za} 1139$ & K & 29 C $1141 *$ & 150 & & Sabia & & \\
\hline Kazak & $\begin{array}{l}\text { Mehmed } \\
\text { Selim }\end{array}$ & $1 \mathrm{~B} 1141 *$ & K & $30 \mathrm{Z} 1142$ & 150 & Ref & & & \\
\hline Kazak & Mehmed & $1 \mathrm{M} 1143$ & K & 29 Z 1144 * & 150 & & Sabia & & \\
\hline Kazak & Süleyman & & K & 30 B 1145 & & Ref & & & \\
\hline Kazak & $\begin{array}{l}\text { es-Seyyid } \\
\text { Mustafa }\end{array}$ & 1 Ş 1145 & K & $29 \mathrm{C} 1146$ & 150 & Ref & & & \\
\hline Kazak & $\begin{array}{l}\text { Mehmed } \\
\text { Said }\end{array}$ & $1 \mathrm{~B} 1146$ & K & $29 \mathrm{~S} 1148 *$ & 150 & & & & \\
\hline $\begin{array}{l}\text { Kirmanşa- } \\
\text { han }\end{array}$ & $\begin{array}{l}\text { es-Seyyid } \\
\text { İbrahim }\end{array}$ & $1 \mathrm{Ra} 1137$ & K & $1-6$ C 1137 * & 499 & Vefat & Sitte & & \\
\hline $\begin{array}{l}\text { Kirmanşa- } \\
\text { han }\end{array}$ & $\begin{array}{l}\text { Alizâde } \\
\text { Mustafa }\end{array}$ & & $\dot{I}$ & $30 \mathrm{Ra} 1141$ & & Ref & & & \\
\hline
\end{tabular}




\begin{tabular}{|c|c|c|c|c|c|c|c|c|c|}
\hline Kaza & Kadı İsmi & $\begin{array}{c}\text { Göreve } \\
\text { Başlama } \\
\text { Tarihi }\end{array}$ & $\begin{array}{l}\text { Tevcih } \\
\text { Şekli }\end{array}$ & $\begin{array}{c}\text { Ayrilma } \\
\text { Tarihi }\end{array}$ & $\begin{array}{c}\text { Atandığı } \\
\text { Derece }\end{array}$ & $\begin{array}{c}\text { Görev } \\
\text { Bitiş } \\
\text { Sebebi }\end{array}$ & $\begin{array}{c}\text { Kazanın } \\
\text { Rütbesi }\end{array}$ & $\begin{array}{l}\text { İlhak } \\
\text { Kazası }\end{array}$ & \begin{tabular}{|c} 
Başka \\
Kazada \\
Görev \\
Süresi \\
(Ay)
\end{tabular} \\
\hline $\begin{array}{l}\text { Kirmanşa- } \\
\text { han }\end{array}$ & $\begin{array}{l}\text { Hıfzızâde } \\
\text { Mehmed }\end{array}$ & $1 \mathrm{R} 1141 *$ & K & 30 Ra $1143 *$ & 499 & & Sitte & $\begin{array}{l}\text { Hersin } \\
\text { ve sâ'ir } \\
\text { Nevâhi }\end{array}$ & \\
\hline Lori & $\begin{array}{l}\text { es-Seyyid } \\
\text { Mehmed }\end{array}$ & $1 \mathrm{~N} 1136$ & K & $29 \mathrm{R} 1138$ & 200 & Ref & Hamise & & \\
\hline Lori & Veliyüddin & $29 \mathrm{R} 1138$ & K & $30 \mathrm{Z} 1139$ & 150 & Ref & & & \\
\hline Lori & Halil & $1 \mathrm{M} 1140$ & K & $29 \mathrm{R} 1141$ & 200 & Ref & & & \\
\hline Lori & $\begin{array}{l}\text { es-Seyyid } \\
\text { Osman }\end{array}$ & $1 \mathrm{Ca} 1141$ & K & 29 R $1143 *$ & 200 & & & $\begin{array}{c}\text { Şüregel } \\
\text { ve Abaran } \\
\text { ve İlli ve } \\
\text { Hıdır Bey } \\
\text { nahiyeleri }\end{array}$ & \\
\hline Lori & $\begin{array}{l}\text { es-Seyyid } \\
\text { Mustafa }\end{array}$ & $1 \mathrm{Ca} 1143 *$ & K & 30 N $1144 *$ & & & & & \\
\hline Lori & Mehmed & $1 \mathrm{~L} 1144$ & K & $30 \mathrm{Ra} 1146$ & 200 & Ref & & & \\
\hline Lori & $\begin{array}{l}\text { el-Hac } \\
\text { Mustafa }\end{array}$ & $1 \mathrm{R} 1146$ & K & $30 \mathrm{Ra} 1147$ & 200 & Ref & Hamise & & \\
\hline Lori & Mustafa & $1 \mathrm{R} 1147$ & K & $30 \mathrm{Za} 1147$ & 200 & Ref & & $\begin{array}{c}\text { Halhane } \\
\text { ma'a Şem- } \\
\text { seddin ve } \\
\text { Penbe ve } \\
\text { Ağcekal'a }\end{array}$ & 10 \\
\hline Lori & İbrahim & $1 \mathrm{Z} 1147$ & K & 30 B $1149 *$ & 200 & & Hamise & $\begin{array}{c}\text { Halhane } \\
\text { ve Şem- } \\
\text { seddin ve } \\
\text { Ağceka- } \\
\text { la'a ve } \\
\text { Kazak }\end{array}$ & \\
\hline $\begin{array}{l}\text { Lorstan } \\
\text { ma‘a Hür- } \\
\text { remabad }\end{array}$ & Hafız Ali & $\begin{array}{c}1 \mathrm{C} 1138 / 1 \\
\text { B } 1138\end{array}$ & K & $29 \mathrm{C} 1140 *$ & 150 & & Sabia & & \\
\hline
\end{tabular}




\begin{tabular}{|c|c|c|c|c|c|c|c|c|c|}
\hline Kaza & Kadı İsmi & $\begin{array}{c}\text { Göreve } \\
\text { Başlama } \\
\text { Tarihi }\end{array}$ & $\begin{array}{c}\text { Tevcih } \\
\text { Şekli }\end{array}$ & $\begin{array}{c}\text { Ayrilma } \\
\text { Tarihi }\end{array}$ & $\begin{array}{c}\text { Atandığı } \\
\text { Derece }\end{array}$ & $\begin{array}{c}\text { Görev } \\
\text { Bitiş } \\
\text { Sebebi }\end{array}$ & $\begin{array}{l}\text { Kazanın } \\
\text { Rütbesi }\end{array}$ & $\begin{array}{l}\text { İlhak } \\
\text { Kazası }\end{array}$ & $\begin{array}{c}\text { Başka } \\
\text { Kazada } \\
\text { Görev } \\
\text { Süresi } \\
\text { (Ay) }\end{array}$ \\
\hline Mekû & Hasan & $1 \mathrm{~N} 1137$ & K & 30 B 1138 & 200 & Ref & Hamise & & \\
\hline Mekû & Mehmed & 1 Ş 1138 & K & $29 \mathrm{~S} 1141$ & 200 & Ref & Rabia & & \\
\hline Mekû & \begin{tabular}{|l|} 
es-Seyyid \\
Şeyh \\
Mahmud
\end{tabular} & $1 \mathrm{Ra} 1141$ & K & $29 \mathrm{~S} 1143 *$ & 150 & & Sabia & Bayezid & \\
\hline $\begin{array}{l}\text { Mencah } \\
\text { Cemaati }\end{array}$ & \begin{tabular}{|l|} 
Halil \\
{$[$ Cemaatin } \\
lideri $]$
\end{tabular} & 1 M 1141 & $\mathrm{~T}$ & & 40 & & & & \\
\hline Meraga & Ahmed & $1 \mathrm{~N} 1138$ & K & 29 Ş 1140 * & 200 & & Rabia & $?$ & \\
\hline Meraga & $\begin{array}{l}\text { Gümüş- } \\
\text { haneli } \\
\text { Mehmed }\end{array}$ & $1 \mathrm{~N} 1144$ & K & 29 R 1146 * & 100 & & Sadise & & \\
\hline Nahcivan & Süleyman & $1 \mathrm{~N} 1137$ & K & 29 Ş 1139 & & Ref & Sitte & $\begin{array}{c}\text { Yezidabad } \\
\text { ve Şerür }\end{array}$ & \\
\hline Nahcivan & Receb & $1 \mathrm{~N} 1139$ & K & $30 \mathrm{Ra} 1141$ & 499 & Azl & & $\begin{array}{c}\text { Yezidabad } \\
\text { ve Şerür }\end{array}$ & \\
\hline Nahcivan & el-Hac Ali & 1 R 1141 & K & $30 \mathrm{Ra} 1143$ & 499 & Ref & & $\begin{array}{c}\text { Yezidabad } \\
\text { ve Şerür } \\
\text { ve Oru- } \\
\text { duabad } \\
\text { ve Meren } \\
\text { nahiyesi }\end{array}$ & \\
\hline Nahcivan & $\begin{array}{l}\text { Sadizâde } \\
\text { es-Seyyid } \\
\text { Seyfullah }\end{array}$ & 1 R 1143 & K & 29 Ş 1144 * & 499 & & Üsküdar & $\begin{array}{c}\text { Merend ve } \\
\text { Şerür ve } \\
\text { Ordubad }\end{array}$ & \\
\hline Nahcivan & $\begin{array}{l}\text { el-Hac } \\
\text { Mehmed }\end{array}$ & $1 \mathrm{~N} 1144$ & K & $29 \mathrm{~S} 1146$ & & Ref & Saniye & $\begin{array}{c}\text { Merend ve } \\
\text { Yezidabad } \\
\text { ve Şerür } \\
\text { ve Ordu- } \\
\text { bad }\end{array}$ & \\
\hline
\end{tabular}




\begin{tabular}{|c|c|c|c|c|c|c|c|c|c|}
\hline Kaza & Kadı İsmi & $\begin{array}{c}\text { Göreve } \\
\text { Başlama } \\
\text { Tarihi }\end{array}$ & $\begin{array}{l}\text { Tevcih } \\
\text { Şekli }\end{array}$ & $\begin{array}{c}\text { Ayrılma } \\
\text { Tarihi }\end{array}$ & $\begin{array}{c}\text { Atandığı } \\
\text { Derece }\end{array}$ & $\begin{array}{c}\text { Görev } \\
\text { Bitiş } \\
\text { Sebebi }\end{array}$ & $\begin{array}{l}\text { Kazanın } \\
\text { Rütbesi }\end{array}$ & $\begin{array}{c}\text { İlhak } \\
\text { Kazası }\end{array}$ & $\begin{array}{c}\text { Başka } \\
\text { Kazada } \\
\text { Görev } \\
\text { Süresi } \\
\text { (Ay) }\end{array}$ \\
\hline Nahcivan & $\begin{array}{l}\text { Ahmed } \\
\text { Reşid }\end{array}$ & $1 \mathrm{Ra} 1146$ & K & 30 B 1147 & 200 & Ref & $\begin{array}{c}\text { Rabia ve } \\
\text { Salise }\end{array}$ & $\begin{array}{l}\text { Ordubad } \\
\text { ve Yez- } \\
\text { duvar ve } \\
\text { Serür ve } \\
\text { Kapan }\end{array}$ & \\
\hline Nahcivan & $\begin{array}{l}\text { es-Seyyid } \\
\text { Derviş Ali }\end{array}$ & 1 Ş 1147 & K & 30 Ra $1149 *$ & & & Rabia & $\begin{array}{c}\text { Ordubad } \\
\text { ve Yez- } \\
\text { duvar ve } \\
\text { Şerür ve } \\
\text { Kapan }\end{array}$ & \\
\hline Nahcivan & Mustafa & 1 R $1149 *$ & K & $30 \mathrm{Za} 1150 *$ & 200 & & & $\begin{array}{c}\text { Ordubad } \\
\text { ve Yez- } \\
\text { duvar ve } \\
\text { Şerür ve } \\
\text { Kapan }\end{array}$ & \\
\hline $\begin{array}{l}\text { Ostan ma'a } \\
\text { Nahiye-i } \\
\text { Vizabad }\end{array}$ & $\begin{array}{l}\text { es-Seyyid } \\
\text { el-Hac } \\
\text { Mehmed } \\
\text { Said }\end{array}$ & $1 \mathrm{Ca} 1141$ & K & $29 \mathrm{R} 1143$ & 150 & Ref & Sabia & & \\
\hline $\begin{array}{l}\text { Ostan ma'a } \\
\text { Nahiye-i } \\
\text { Vizabad }\end{array}$ & Ali & $1 \mathrm{Ca} 1143$ & K & 29 R 1145 * & 150 & & & & \\
\hline Pesyan & Ahmed & $1 \mathrm{Ra} 1138$ & K & $29 \mathrm{~S} 1140 *$ & 150 & & Samine & $?$ & \\
\hline Pesyan & Mustafa & $1 \mathrm{Ra} 1140 *$ & K & $29 \mathrm{~S} 1142 *$ & 150 & & & & \\
\hline $\begin{array}{l}\text { Saderda } \\
\text { ma'a Veda } \\
\text { [Saderek } \\
\text { ma'a Vedi] }\end{array}$ & $\begin{array}{l}\text { es-Seyyid } \\
\text { Hasan }\end{array}$ & & K & 29 R 1139 & & Ref & & & \\
\hline $\begin{array}{l}\text { Saderda } \\
\text { ma'a Veda } \\
\text { [Saderek } \\
\text { ma'a Vedi] }\end{array}$ & Mahmud & $1 \mathrm{Ca} 1139$ & K & 29 Z 1140 * & 150 & & & & \\
\hline
\end{tabular}




\begin{tabular}{|c|c|c|c|c|c|c|c|c|c|}
\hline Kaza & Kadı İsmi & $\begin{array}{c}\text { Göreve } \\
\text { Başlama } \\
\text { Tarihi }\end{array}$ & $\begin{array}{c}\text { Tevcih } \\
\text { Şekli }\end{array}$ & $\begin{array}{c}\text { Ayrilma } \\
\text { Tarihi }\end{array}$ & $\begin{array}{c}\text { Atandığı } \\
\text { Derece }\end{array}$ & $\begin{array}{c}\text { Görev } \\
\text { Bitiş } \\
\text { Sebebi }\end{array}$ & $\begin{array}{l}\text { Kazanın } \\
\text { Rütbesi }\end{array}$ & $\begin{array}{l}\text { İlhak } \\
\text { Kazası }\end{array}$ & $\begin{array}{c}\text { Başka } \\
\text { Kazada } \\
\text { Görev } \\
\text { Süresi } \\
\text { (Ay) }\end{array}$ \\
\hline Somhit & Ali & $1 \mathrm{~N} 1136$ & K & $29 \mathrm{~S} 1138$ & 200 & Ref & Sabia & & \\
\hline Somhit & Osman & $1 \mathrm{Ra} 1138$ & K & $29 \mathrm{R} 1139$ & 150 & Ref & & & \\
\hline Somhit & $\begin{array}{l}\text { es-Seyyid } \\
\text { Ahmed }\end{array}$ & $1 \mathrm{Ca} 1139$ & K & $30 \mathrm{Ra} 1141$ & 150 & $\begin{array}{c}\text { Bi-berat } \\
\text { Ref }\end{array}$ & & & \\
\hline Somhit & Ali & 1 R 1141 & K & $30 \mathrm{Za} 1142$ & 150 & Ref & & & \\
\hline Somhit & $\begin{array}{l}\text { Tobzâde } \\
\text { es-Seyyid } \\
\text { Mehmed } \\
\text { Salih }\end{array}$ & $1 \mathrm{Z} 1142$ & K & $30 \mathrm{Za} 1144 *$ & 150 & & & & \\
\hline Somhit & İbrahim & & K & $30 \mathrm{Ca} 1145$ & & Ref & & & \\
\hline Somhit & $\begin{array}{l}\text { es-Seyyid } \\
\text { Abdullah }\end{array}$ & $1 \mathrm{C} 1145$ & K & $30 \mathrm{M} 1147 *$ & 150 & & & ? & \\
\hline $\begin{array}{l}\text { Sultaniye } \\
\text { ve Zencan }\end{array}$ & $\begin{array}{l}\text { es-Seyyid } \\
\text { Mustafa }\end{array}$ & $1 \mathrm{Ra} 1139$ & K & $29 \mathrm{~S} 1141$ & 200 & Ref & Sadise & & \\
\hline $\begin{array}{l}\text { Sultaniye } \\
\text { ve Zencan }\end{array}$ & $\begin{array}{l}\text { es-Seyyid } \\
\text { Mehmed }\end{array}$ & $1 \mathrm{Ra} 1141$ & K & $30 \mathrm{M} 1143$ & 200 & Nakl & & Ebher & \\
\hline $\begin{array}{l}\text { Sultaniye } \\
\text { ve Zencan }\end{array}$ & $\begin{array}{l}\text { Bağdadi } \\
\text { Şemseddin }\end{array}$ & $1 \mathrm{~S} 1143$ & K & 30 M 1145 * & 499 & & Sadise & & \\
\hline $\begin{array}{l}\text { Sürmeli } \\
\text { ma'a Iğdır }\end{array}$ & Mustafa & $1 \mathrm{~N} 1137$ & K & $30 \mathrm{Za} 1137$ & 200 & Vefat & Hamise & & \\
\hline $\begin{array}{l}\text { Sürmeli } \\
\text { ma'a Iğdır }\end{array}$ & Ebubekir & $1 \mathrm{Z} 1137$ & K & 29 Ş 1139 & & Ref & & & \\
\hline $\begin{array}{l}\text { Sürmeli } \\
\text { ma'a Iğdır }\end{array}$ & Ali & 1 N 1139 & K & $29 \mathrm{~S} 1141$ & 200 & Ref & & & \\
\hline $\begin{array}{l}\text { Sürmeli } \\
\text { ma'a Iğdır }\end{array}$ & Ömer & $1 \mathrm{Ra} 1141$ & K & $30 \mathrm{~N} 1142$ & 200 & Ref & Rabia & $\begin{array}{c}\text { Sadrade } \\
\text { ma'a Vedi } \\
{[\text { Saderek }} \\
\text { ma'a Vedi }]\end{array}$ & \\
\hline
\end{tabular}




\begin{tabular}{|c|c|c|c|c|c|c|c|c|c|}
\hline Kaza & Kadı İsmi & $\begin{array}{c}\text { Göreve } \\
\text { Başlama } \\
\text { Tarihi }\end{array}$ & $\begin{array}{c}\text { Tevcih } \\
\text { Şekli }\end{array}$ & $\begin{array}{c}\text { Ayrılma } \\
\text { Tarihi }\end{array}$ & $\begin{array}{c}\text { Atandı̆̆ } \\
\text { Derece }\end{array}$ & $\begin{array}{c}\text { Görev } \\
\text { Bitiş } \\
\text { Sebebi }\end{array}$ & $\begin{array}{l}\text { Kazanın } \\
\text { Rütbesi }\end{array}$ & $\begin{array}{l}\text { İlhak } \\
\text { Kazası }\end{array}$ & $\begin{array}{c}\text { Başka } \\
\text { Kazada } \\
\text { Görev } \\
\text { Süresi } \\
\text { (Ay) }\end{array}$ \\
\hline $\begin{array}{l}\text { Sürmeli } \\
\text { ma‘a Iğdır }\end{array}$ & $\begin{array}{l}\text { Ezber- } \\
\text { cizâde } \\
\text { Mustafa }\end{array}$ & $1 \mathrm{~L} 1142$ & K & $30 \mathrm{~N} 1144$ * & 200 & Ref & Sadise & $\begin{array}{c}\text { Sadrade } \\
\text { ma'a Vedi } \\
\text { [Saderek } \\
\text { ma'a Vedi] }\end{array}$ & \\
\hline $\begin{array}{l}\text { Sürmeli } \\
\text { ma‘a Iğdır }\end{array}$ & $\begin{array}{l}\text { Tobzâde } \\
\text { es-Seyyid } \\
\text { Mehmed } \\
\text { Salih }\end{array}$ & $1 \mathrm{~L} 1144 *$ & K & $30 \mathrm{Za} 1144$ & & Ref & & & \\
\hline $\begin{array}{l}\text { Sürmeli } \\
\text { ma‘a Iğdır }\end{array}$ & $\begin{array}{l}\text { es-Seyyid } \\
\text { Ali }\end{array}$ & $1 \mathrm{Z} 1144$ & K & 30 B 1145 & 200 & Ref & Sadise & & \\
\hline $\begin{array}{l}\text { Sürmeli } \\
\text { ma'a Iğdır }\end{array}$ & $\begin{array}{l}\text { es-Seyyid } \\
\text { Mustafa }\end{array}$ & 1 Ş 1145 & K & 30 B 1146 & 200 & Ref & & & \\
\hline $\begin{array}{l}\text { Sürmeli } \\
\text { ma‘a Iğdır }\end{array}$ & $\begin{array}{l}\text { Merha- } \\
\text { bazâde } \\
\text { es-Seyyid } \\
\text { Feyzullah }\end{array}$ & 30 B 1146 & K & $30 \mathrm{Ra} 1148 *$ & 150 & & & & \\
\hline $\begin{array}{l}\text { Sürmeli } \\
\text { ma‘a Iğdır }\end{array}$ & Abdullah & $1 \mathrm{R} 1148$ * & K & $30 \mathrm{Za} 1149 *$ & 150 & & Sabia & Mekû & \\
\hline $\begin{array}{l}\text { Şemsed- } \\
\text { dinlü ma'a } \\
\text { Halhane }\end{array}$ & $\begin{array}{l}\text { es-Seyyid } \\
\text { el-Hac } \\
\text { Mehmed }\end{array}$ & $1 \mathrm{Ra} 1138$ & K & $29 \mathrm{~S} 1140 *$ & 300 & & Saniye & & \\
\hline $\begin{array}{l}\text { Şemsed- } \\
\text { dinlü ma'a } \\
\text { Halhane }\end{array}$ & Ahmed & $1 \mathrm{Ra} 1140 *$ & K & $29 \mathrm{~S} 1142 *$ & 300 & & Saniye & & \\
\hline Şirvan & $\begin{array}{l}\text { Abdurrez- } \\
\text { zak }\end{array}$ & $1 \mathrm{C} 1138$ & K & & 150 & & Sadise & Şemahi & \\
\hline Şirvan & “ & $1 \mathrm{Za} 1138$ & $\mathrm{~T}$ & $29 \mathrm{~S} 1139$ & & & & Şemahi & \\
\hline Şirvan & Eyüb & $1 \mathrm{Ra} 1139$ & $\mathrm{~T}$ & & & & & Şemahi & \\
\hline Şirvan & “ & $1 \mathrm{M} 1145$ & $\mathrm{~T}$ & & & & & Şemahi & \\
\hline
\end{tabular}




\begin{tabular}{|c|c|c|c|c|c|c|c|c|c|}
\hline Kaza & Kadı İsmi & $\begin{array}{c}\text { Göreve } \\
\text { Başlama } \\
\text { Tarihi }\end{array}$ & $\begin{array}{c}\text { Tevcih } \\
\text { Şekli }\end{array}$ & $\begin{array}{c}\text { Ayrılma } \\
\text { Tarihi }\end{array}$ & $\begin{array}{c}\text { Atandığ } \\
\text { Derece }\end{array}$ & $\begin{array}{c}\text { Görev } \\
\text { Bitiş } \\
\text { Sebebi }\end{array}$ & $\begin{array}{l}\text { Kazanın } \\
\text { Rütbesi }\end{array}$ & $\begin{array}{l}\text { İlhak } \\
\text { Kazası }\end{array}$ & $\begin{array}{c}\text { Başka } \\
\text { Kazada } \\
\text { Görev } \\
\text { Süresi } \\
\text { (Ay) }\end{array}$ \\
\hline $\begin{array}{l}\text { Şüregel } \\
\text { ve Abaran } \\
\text { nahiyeleri }\end{array}$ & $\begin{array}{l}\text { es-Seyyid } \\
\text { Abdurrah- } \\
\text { man }\end{array}$ & 1 M 1139 & K & 29 Z $1140 *$ & & & Sabia & & \\
\hline Tabtâb & $\begin{array}{l}\text { es-Seyyid } \\
\text { Mustafa }\end{array}$ & $1 \mathrm{Ra} 1138$ & K & 29 C $1139 *$ & 150 & & Sabia & & \\
\hline Tabtâb & $\begin{array}{l}\text { es-Seyyid } \\
\text { Mustafa }\end{array}$ & 1 B $1139 *$ & K & 29 S $1141 *$ & 150 & & Sabia & & \\
\hline Tesûc & $\begin{array}{l}\text { es-Seyyid } \\
\text { Mehmed }\end{array}$ & $1 \mathrm{~L} 1137$ & K & 29 R 1138 & & Ref & Rabia & & \\
\hline Tesûc & $\begin{array}{l}\text { el-Hac } \\
\text { Abdullah }\end{array}$ & $1 \mathrm{Ca} 1138$ & K & $30 \mathrm{Za} 1139$ & 200 & Ref & Salise & & \\
\hline Tesûc & Abdullah & $1 \mathrm{Z} 1139$ & K & 29 Ş 1141 & 300 & Ref & Saniye & & \\
\hline Tesûc & $\begin{array}{l}\text { el-hac } \\
\text { Ömer }\end{array}$ & $1 \mathrm{~N} 1141$ & K & 29 C 1142 & 200 & Ref & Sadise & & \\
\hline Tesûc & $\begin{array}{l}\text { es-Seyyid } \\
\text { Feyzullah }\end{array}$ & 1 B 1142 & K & 29 S $1144 *$ & 200 & & & & \\
\hline Tesûc & Ahmed & $1 \mathrm{~N} 1144$ & K & 29 Ş 1145 * & 200 & & Sadise & & \\
\hline Tiflis & Ömer & 29 Ş 1136 & $\begin{array}{c}\text { Mevle- } \\
\text { viyet }\end{array}$ & & & Ref & & & \\
\hline Tiflis & $\begin{array}{l}\text { Hafizzâde } \\
\text { es-Seyyid } \\
\text { Ebubekir }\end{array}$ & $1 \mathrm{~N} 1136$ & K & $30 \mathrm{Ca} 1138$ & 300 & Ref & Saniye & & \\
\hline Tifflis & Hasan & 1 B 1138 & K & 29 S 1140 & 400 & Ref & $\begin{array}{c}\text { Saniye ve } \\
\text { Mûsıla }\end{array}$ & & \\
\hline Tiflis & Mustafa & $1 \mathrm{Ra} 1140$ & K & 29 R 1142 & 300 & Ref & $\begin{array}{c}\text { Mûsıla ve } \\
\text { Sitte }\end{array}$ & & \\
\hline Tiflis & $\begin{array}{l}\text { el-Hac } \\
\text { Mehmed }\end{array}$ & $1 \mathrm{Ca} 1142$ & K & $1 \mathrm{Za} 1142$ & 499 & Vefat & Sitte & & \\
\hline Tiflis & $\begin{array}{l}\text { Mehmed } \\
\text { Emin }\end{array}$ & $1 \mathrm{M} 1143$ & K & 29 Z 1144 & 499 & Ref & & & \\
\hline
\end{tabular}




\begin{tabular}{|c|c|c|c|c|c|c|c|c|c|}
\hline Kaza & Kadı İsmi & $\begin{array}{c}\text { Göreve } \\
\text { Başlama } \\
\text { Tarihi }\end{array}$ & $\begin{array}{c}\text { Tevcih } \\
\text { Şekli }\end{array}$ & $\begin{array}{c}\text { Ayrılma } \\
\text { Tarihi }\end{array}$ & $\begin{array}{c}\text { Atandığg } \\
\text { Derece }\end{array}$ & $\begin{array}{c}\text { Görev } \\
\text { Bitiş } \\
\text { Sebebi }\end{array}$ & $\begin{array}{c}\text { Kazanın } \\
\text { Rütbesi }\end{array}$ & $\begin{array}{l}\text { İlhak } \\
\text { Kazası }\end{array}$ & $\begin{array}{c}\text { Başka } \\
\text { Kazada } \\
\text { Görev } \\
\text { Süresi } \\
\text { (Ay) }\end{array}$ \\
\hline Tiflis & $\begin{array}{l}\text { Tobzâde } \\
\text { es-Seyyid } \\
\text { Mehmed }\end{array}$ & $1 \mathrm{M} 1145$ & K & $30 \mathrm{Ca} 1146$ & 499 & Ref & Sitte & & \\
\hline Tiflis & $\begin{array}{l}\text { es-Seyyid } \\
\text { Mustafa }\end{array}$ & $1 \mathrm{C} 1146$ & K & 30 M 1148 & 499 & Ref & & & \\
\hline Tiflis & $\begin{array}{l}\text { el-Hac } \\
\text { Ahmed }\end{array}$ & $1 \mathrm{~S} 1148$ & K & 30 N 1149 * & 400 & & Mûsıla & $\begin{array}{l}\text { Tiryalit } \\
\text { ve Gori, } \\
\text { Somhit }\end{array}$ & \\
\hline Tiryalit & $\begin{array}{l}\text { Hatibzâde } \\
\text { Mustafa }\end{array}$ & $1 \mathrm{~N} 1136$ & K & $29 \mathrm{~S} 1138$ & 200 & Ref & Sabia & & \\
\hline Tiryalit & İsmail & $1 \mathrm{Ra} 1138$ & K & 29 Ş $1139^{*}$ & 200 & & Sadise & & \\
\hline Tiryalit & $\begin{array}{l}\text { es-Seyyid } \\
\text { Abdurrah- } \\
\text { man }\end{array}$ & $1 \mathrm{~N} 1139 *$ & K & $29 \mathrm{~S} 1141$ & 150 & Ref & Sadise & & \\
\hline Tiryalit & Mahmud & $1 \mathrm{Ra} 1141$ & K & $30 \mathrm{Ra} 1142$ & 150 & Ref & Sadise & & 8 \\
\hline Tiryalit & Ali & $1 \mathrm{R} 1142$ & K & $30 \mathrm{Za} 1143 *$ & 150 & & & Cevasad & \\
\hline $\begin{array}{l}\text { Tobkaraa- } \\
\text { ğacı }\end{array}$ & $\begin{array}{l}\text { Abdulke- } \\
\text { rim }\end{array}$ & $1 \mathrm{~L} 1145$ & K & $29 \mathrm{Ca} 1146$ & 200 & Ref & & & \\
\hline Tusergan? & Mustafa & $1 \mathrm{Z} 1142$ & K & & 150 & & Samine & $\begin{array}{c}\text { Kenek? } \\
\text { Avret- } \\
\text { bir? ve } \\
\text { Cevard? }\end{array}$ & \\
\hline Urumiye & İsmail & 1 Ş 1138 & K & $30 \mathrm{Za} 1139$ & 499 & Ref & Sitte & & \\
\hline Urumiye & $\begin{array}{l}\text { Tuğcızâde } \\
\text { Mustafa }\end{array}$ & 1 Z 1139 & K & $30 \mathrm{Za} 1140$ & 300 & $\begin{array}{c}\text { Bi-berat/ } \\
\text { Ref }\end{array}$ & Salise & $\begin{array}{c}\text { Kütatis } \\
\text { ma'a Bağ- } \\
\text { dadcık }\end{array}$ & \\
\hline Urumiye & $\begin{array}{l}\text { es-Seyyid } \\
\text { Mehmed }\end{array}$ & $1 \mathrm{Z} 1140$ & K & $30 \mathrm{Za} 1142$ & 300 & Ref & Saniye & & \\
\hline Urumiye & $\begin{array}{l}\text { Tobzâde } \\
\text { es-Seyyid } \\
\text { Mehmed }\end{array}$ & $1 \mathrm{Z} 1142$ & K & & 300 & & Saniye & $\begin{array}{c}\text { Kütatis } \\
\text { ma'a Bağ- } \\
\text { dadcık }\end{array}$ & \\
\hline
\end{tabular}




\begin{tabular}{|l|l|c|c|c|c|c|c|c|c|}
\hline Kaza & Kadı İsmi & $\begin{array}{c}\text { Göreve } \\
\text { Başlama } \\
\text { Tarihi }\end{array}$ & $\begin{array}{c}\text { Tevcih } \\
\text { Şekli }\end{array}$ & $\begin{array}{c}\text { Ayrılma } \\
\text { Tarihi }\end{array}$ & $\begin{array}{c}\text { Atandı̆̆ı } \\
\text { Derece }\end{array}$ & $\begin{array}{c}\text { Görev } \\
\text { Bitiş } \\
\text { Sebebi }\end{array}$ & $\begin{array}{c}\text { Kazanın } \\
\text { Rütbesi }\end{array}$ & $\begin{array}{c}\text { Başka } \\
\text { IIlhak } \\
\text { Kazası } \\
\text { Kazada } \\
\text { Görev } \\
\text { Süresi } \\
\text { (Ay) }\end{array}$ \\
\hline Urumiye & İsmail & 1 Ş 1144 & $\mathrm{~K}$ & $30 \mathrm{Ra} 1146 *$ & 400 & & & & \\
\hline Zarzebil & Ömer & & $\mathrm{K}$ & $29 \mathrm{~S} 1139$ & & Ref & Sadise & & \\
\hline Zarzebil & Mehmed & $1 \mathrm{Ra} 1139$ & $\mathrm{~K}$ & $29 \mathrm{~S} 1140 *$ & 200 & & Sadise & & \\
\hline Zarzebil & $\begin{array}{l}\text { Müftizâde } \\
\text { Mehmed }\end{array}$ & $1 \mathrm{~N} 1140 *$ & $\mathrm{~K}$ & $29 \mathrm{R} 1142 *$ & 200 & & & & \\
\hline
\end{tabular}


